\title{
Review \\ The Multifactorial Progression from the Islet Autoimmunity to Type 1 Diabetes in Children
}

\author{
Witold Bauer $1, * \mathbb{C}$, Attila Gyenesei ${ }^{1,2}$ and Adam Krętowski ${ }^{1,3}$ \\ 1 Clinical Research Centre, Medical University of Białystok, Marii Skłodowskiej-Curie 24a, \\ 15-276 Białystok, Poland; gyenesei.attila@pte.hu (A.G.); adamkretowski@wp.pl (A.K.) \\ 2 Szentágothai Research Centre, University of Pécs, Ifjúság útja 20, 7624 Pécs, Hungary \\ 3 Department of Endocrinology, Diabetology and Internal Medicine, Medical University of Białystok, \\ Marii Skłodowskiej-Curie 24a, 15-276 Białystok, Poland \\ * Correspondence: witold.bauer@umb.edu.pl; Tel.: +48-85-831-8150
}

check for updates

Citation: Bauer, W.; Gyenesei, A.; Krẹtowski, A. The Multifactorial Progression from the Islet Autoimmunity to Type 1 Diabetes in Children. Int. J. Mol. Sci. 2021, 22, 7493. https://doi.org/10.3390/ ijms22147493

Academic Editor: Jens Høiriis Nielsen

Received: 16 June 2021

Accepted: 9 July 2021

Published: 13 July 2021

Publisher's Note: MDPI stays neutral with regard to jurisdictional claims in published maps and institutional affiliations.

Copyright: (c) 2021 by the authors. Licensee MDPI, Basel, Switzerland. This article is an open access article distributed under the terms and conditions of the Creative Commons Attribution (CC BY) license (https:/ / creativecommons.org/licenses/by/ $4.0 /)$.

\begin{abstract}
Type 1 Diabetes (T1D) results from autoimmune destruction of insulin producing pancreatic B-cells. This disease, with a peak incidence in childhood, causes the lifelong need for insulin injections and necessitates careful monitoring of blood glucose levels. However, despite the current insulin therapies, it still shortens life expectancy due to complications affecting multiple organs. Recently, the incidence of T1D in childhood has increased by 3-5\% per year in most developed Western countries. The heterogeneity of the disease process is supported by the findings of follow-up studies started early in infancy. The development of T1D is usually preceded by the appearance of autoantibodies targeted against antigens expressed in the pancreatic islets. The risk of T1D increases significantly with an increasing number of positive autoantibodies. The order of autoantibody appearance affects the disease risk. Genetic susceptibility, mainly defined by the human leukocyte antigen (HLA) class II gene region and environmental factors, is important in the development of islet autoimmunity and T1D. Environmental factors, mainly those linked to the changes in the gut microbiome as well as several pathogens, especially viruses, and diet are key modulators of T1D. The aim of this paper is to expand the understanding of the aetiology and pathogenesis of T1D in childhood by detailed description and comparison of factors affecting the progression from the islet autoimmunity to T1D in children.
\end{abstract}

Keywords: type 1 diabetes; T1D prediction; islet autoantibodies; HLA; gut microbiome

\section{Introduction}

Type 1 diabetes (T1D) is a chronic endocrine disease that results from autoimmune destruction of insulin-producing $\beta$-cells in the pancreas after the asymptomatic period of various duration [1-3].

The development of T1D is a heterogeneous process, usually proceeded by the appearance of islet-specific autoantibodies against $\beta$-cells structures. Among the autoantibodies which are construed as a sign of ongoing $\beta$-cells destruction, islet cell cytoplasmic autoantibodies (ICA), and biochemical autoantibodies targeted to insulin (IAA), islet antigen-2 protein (IA-2A), glutamic acid decarboxylase (GADA) and zinc transporter 8 (ZnT8A) are the best characterised [4]. The two most common autoantibodies present at seroconversion in childhood are IAA and GADA, whereas IA-2A and ZnT8A autoantibodies appear as the first ones in a relatively small proportion. However, they are all common at the diagnosis of the disease $[5,6]$. Later in the disease, disturbances in glucose metabolism become more common as $\beta$-cell destruction proceeds.

The age of seroconversion differs between various autoantibodies initialising the autoimmunity, reaching its peak before the age of two for IAA, whereas GADA peaks at the age of four to five years and continues to appear at a relatively high level throughout 
childhood [7-9]. The risk of T1D increases with an increasing number of positive autoantibodies [10-13]. The observed risk of T1D is time-constant for high IA-2A levels but decrease over time for IAA and GADA [14]. Detailed analysis of this complex relationship, including also ZnT8 autoantibody, is still lacking. A small percentage of genetically susceptible children with islet autoantibodies do not progress to clinical T1D [10]. Other risk factors associated with the rapidity of disease development are genetic susceptibilities, defined by the T1D-associated HLA genotypes and non-HLA associated genes $[15,16]$, age of the appearance of autoantibodies [5], sex $[17,18]$ and probably still unknown environmental factors $[9,19]$. The varying length of the asymptotic phase suggests that environmental elements change the pace of disease progression in addition to genetic factors. The progression from seroconversion to the onset of clinical T1D and progression of islet autoimmunity is also known to be associated with the higher levels of especially IAA [20] and IA-2A [20,21] but also GADA [22,23].

The onset of clinical T1D can occur at any age, but the incidence is highest in childhood [24,25]. In 2019, 463 million people had diabetes, and over one million children and adolescents under the age of twenty had been estimated to have T1D. Type 2 diabetes (T2D) is the most common and accounts for the vast majority (over $90 \%$ ) of diabetes worldwide. The appearance of clinical T1D is associated with a $40-70 \%$ decrease of $\beta$ cells mass, although these numbers differ in children and adult individuals with early stage and long-established diabetes [26]. The global incidence of T1D has been increasing continuously since the middle of the last century, although levelling off in incidence in populations with the highest increase has been recently described $[27,28]$. A decrease in the incidence of T1D in children in the Finnish population was reported recently both in boys and girls in the youngest age group [29]. The ability to predict at an early stage the risk of autoimmunity and T1D progression rates is crucial for selecting appropriately matched case-control groups for trials of preventive treatments. Early detection of autoimmunity is essential in studies on individual risk factors associated with the development of T1D. T1D causes an overwhelming burden on affected children and their families and puts a strain on the health system and society. Children affected with T1D have increased mortality as well as increased risk of cardiovascular comorbidity [30,31]. However, an early diagnosis leads to decreased complications at disease onset $[32,33]$.

This review describes the genetic, immunological and environmental risk factors affecting the progression of islet autoimmunity and progression to clinical T1D in children. The articles presented in this review are limited to the most recent findings, coming from the longitudinal follow-up studies that track general populations, families of patients with T1D and young children at risk of T1D.

\section{Type 1 Diabetes in Children}

\subsection{Aetiology of Diabetes Mellitus}

Diabetes mellitus includes a diverse group of metabolic diseases with the common feature of hyperglycaemia, which can be caused by insufficient insulin secretion and impaired insulin action on target tissues. The typical symptoms of hyperglycaemia include raised urination levels, thirst, weight loss and body fatigue. These symptoms may occur suddenly. Untreated diabetes can result in acute life-threatening complications, like diabetic ketoacidosis and secondary complications in advanced stages of the disease [34]. Diabetes patients have an increased risk of cardiovascular diseases and increased death rates [30,31]. Prior to the discovery of insulin therapy, a patient's life expectancy with T1D was poor, and the disease was generally thought to be fatal. The etiologic classification of diabetes mellitus is complex. Most cases may be categorised into one of two major categories, type 1, or type 2 diabetes (T2D) [34], although more types of diabetes exist, including some caused by the genetic defects of both $\beta$-cell function and insulin action. T1D, which usually appears in childhood, is caused by autoimmune $\beta$-cell destruction, usually leading to absolute insulin deficiency. Immune dysregulation is caused by a combination of underlying genetic and environmental factors that enables autoreactive CD4+ and CD8+ T cells to destroy 
the pancreatic $\beta$-cells [35-37]. T2D is caused by a progressive loss of adequate $\beta$-cell insulin secretion frequently on the background of insulin resistance. The primary etiologic classification was suggested for the first time already in 1951, in a study in which the discrimination between insulin-dependent and non-insulin-dependent diabetes mellitus was stated for the first time [38].

\subsection{Criteria for Diagnosis of T1D}

Typical symptoms of T1D include excessive urination and thirst, which appear along with an unexplained weight loss. American Diabetes Association (ADA) and International Society for Pediatric and Adolescent Diabetes (ISPAD) [34,39] define clear recommendations for diabetes diagnosis. Unless there is an evident clinical diagnosis (children with classic symptoms of hyperglycaemia and a random plasma glucose $\geq 200 \mathrm{mg} / \mathrm{dL}$ $(11.1 \mathrm{mmol} / \mathrm{L}))$, diagnosis requires abnormal test results of fasting glucose $\geq 126 \mathrm{mg} / \mathrm{dL}$ $(7.0 \mathrm{mmol} / \mathrm{L})$, or plasma glucose $\geq 200 \mathrm{mg} / \mathrm{dL}(11.1 \mathrm{mmol} / \mathrm{L}))$ at 2 hours during $75-\mathrm{g}$ oral glucose tolerance test (OGTT). Traditionally, T2D was associated with the occurrence only in adults, while T1D was associated with the rapid development only in children. However, it has been reported that both diseases can occur in all age groups. T2D occurrence is associated with increased age (age $\geq 45$ years old), excess body weight (BMI $\geq 25 \mathrm{~kg} / \mathrm{m}^{2}$ ) and increased body fat percentage, although the exact threshold values differ in different race populations. Although autoimmune destruction of $\beta$-cells does not occur in T2D, at the time of diagnosis, some individuals cannot be clearly classified as having T1D or T2D. Although accurate classification is not straightforward at onset, the diagnosis of T1D becomes more apparent over time in patients with $\beta$-cell deficiency and in patients positive for the islet cell autoantibodies. Three distinct stages of T1D can be identified, with stage one defined by the presence of two or more of these autoimmune markers [34]. The persistent presence of two or more islet autoantibodies is a predictor of clinical hyperglycaemia and diabetes, according to the studies of the first-degree relatives of patients with T1D.

In T1D children, excessive urination and thirst are triggered by glucose levels exceeding the kidney glucose threshold. Due to $\beta$-cell destruction, insulin-sensitive target tissues, such as muscle and adipose tissues, do not receive enough glucose without insulin. In the absence of glucose, energy is produced from free fatty acids and amino acids, which causes weight loss and ketone accumulation. Other symptoms of diabetic ketoacidosis include feeling ill, tired and sleepy; the fruity smell of breath; increased heavy breathing, and confusion.

\subsection{Diabetes Prevalence}

In 2019, 463 million people had diabetes, and over one million children and adolescents under the age of twenty had been estimated to have T1D. According to the International Diabetes Federation, Europe has the highest number of children and adolescents before the age of twenty affected with T1D $(296,500)$. Globally, the United States of America $(175,900)$, India $(171,300)$ and Brazil $(95,800)$ have the highest numbers of children and adolescents with T1D. The incidence rates of T1D are highest in Europe, with over 31,000 new cases each year. In the group of children and adolescents before the age of fourteen, the top countries with the highest annual T1D incidence rates (per 100,000 population) include Finland, Sweden, Norway and United Kingdom in Europe, as well as Kuwait and Saudi Arabia [40].

Before the middle of the last century, the prevalence of T1D was low. The global incidence of T1D has been increasing continuously since the 1950s. However, in populations with the highest increase, the incidence has reached the plateau, and the gradual progress in incidence has been reported to slow down $[27,28]$. Currently, the disease incidence rates continue to rise at the rate of over $3 \%$ per year $[28,40,41]$. According to the estimates, the global number of new cases of T1D in a group of children and adolescents under the age of twenty is 128,900 annually [40]. The increase in the incidence rate was similar among boys and girls in the young and older children, but in tweens and young adolescents, it was 
significantly higher among boys than girls [28]. The high incidence of T1D among children highlights the need for novel research on preventing and delaying the onset of the clinical disease. Since the increase in the incidence rates of T1D is highest in developed countries and lowest in less developed countries, environmental factors are thought to contribute to the disease pathogenesis in addition to the well-established genetic factors.

\subsection{Prediction of $T 1 D$}

The studies on risk factors associated with the development of T1D, precise prediction of progression of autoimmunity as well as ability to forecast the rates of progression to T1D at an early stage using cost-effective screening methods are crucial, given the high economic and social burden associated with the disease [42].

The data currently known about the pathogenesis of T1D comes from longitudinal follow-up studies that track preselected populations at risk of the disease. The choice of the study groups is mostly based on the genetic risk, family history or location of patients, prioritising people from countries with the highest prevalence of T1D. Prediction of T1D is typically based upon screening of HLA risk genotypes and islet cell autoantibodies precise measurements. Although these two techniques are the most reliable and cost-effective, islet cell autoantibodies can only be detected at a certain level when the progression of autoimmunity has already started. This emphasises the need for novel biomarkers of $\beta$ cells dysfunction that could be detectable before the beginning of the autoimmune response. Some of the most extensive prospective studies that focus on populations at risk of T1D are currently run in Finland, Sweden, Germany and the USA. These included the general population studies, families of patients with T1D or young children at risk of T1D. The All Babies in Southwest Sweden (ABIS) study is the most extensive prospective study in Sweden, with over 16,000 subjects enrolled in a cohort [43]. Some of the largest studies that have followed patients with an increased genetic risk of T1D at different ages are The Finnish Type 1 Diabetes Prediction and Prevention (DIPP) study in Finland [44], The Environmental Determinants of the Diabetes in the Young (TEDDY), which is a joint effort of USA, Finland, Sweden and Germany [45], The Diabetes Prediction in Skane (DiPis) in Sweden [46], and The Diabetes Autoimmunity Study in the Young (DAISY) study in the USA [47]. The DIPP and TEDDY projects are both ongoing prospective studies. In addition to this, the relatives of patients at risk of T1D are being followed in several studies, including the German BABYDIAB-BABYDIETY study [48] and an ongoing international TrialNet Pathway to Prevention [49] programme. Precise identification of subpopulations at risk of the disease may allow for personalised prevention clinical trials.

The process of autoimmunity progression and T1D is very heterogeneous, with some of the risk factors still unknown (Table 1) [3]. The root causes of T1D are complex, and novel approaches, besides traditional screening methods, are required to predict the disease onset accurately. In order to reveal potential environmental factors associated with the development of T1D, in 1986-1989 Childhood Diabetes in Finland (DiMe) study was carried out in siblings of children with T1D [50]. DiMe revealed several risk factors associated with the pace of progression of autoimmunity and the development of T1D, such as early exposure to cow's milk formula-feeding and rapid growth in infancy. Systematic patient monitoring also allowed for early detection of new incidences of T1D, particularly among children. 
Table 1. Main categories of factors affecting the progression of islet cell autoimmunity and T1D development.

\begin{tabular}{|c|c|c|}
\hline Risk and Protective Factors & Reported Effects and Associations & References \\
\hline $\begin{array}{l}\text { HLA class II DR3-DQ2 and DR4-DQ8 } \\
\text { haplotypes }\end{array}$ & $\begin{array}{l}\text { Increased risk of rapid progression; expansion of } \\
\text { autoimmunity in children with both IAA- and } \\
\text { GADA-initiated autoimmunity }\end{array}$ & {$[5,51-53]$} \\
\hline HLA class I -A and -B alleles & $\begin{array}{l}\text { Modified age of onset of T1D; increased risk of T1D; } \\
\text { modulated the } \beta \text {-cell destruction }\end{array}$ & {$[54-60]$} \\
\hline $\begin{array}{l}\text { INS, PTPN22, SLC } 30 A 8 \text {, and } B A C H 2 \text { gene } \\
\text { SNPs; alterations in the VNTR region } \\
\text { within the INS gene }\end{array}$ & $\begin{array}{l}\text { Increased progression from islet autoimmunity to } \\
\text { clinical T1D; } \beta \text {-cell destruction early after the initial } \\
\text { seroconversion }\end{array}$ & {$[16,61-68]$} \\
\hline High Genetic Risk Score & $\begin{array}{l}\text { Prediction of T1D; increased progression from islet } \\
\text { autoimmunity to clinical T1D; increased disease } \\
\text { progression pace }\end{array}$ & {$[69-71]$} \\
\hline Young age at autoantibody appearance & Increased risk of T1D & {$[12,18,20]$} \\
\hline Positivity to multiple autoantibodies & $\begin{array}{l}\text { Increased risk of T1D; association with the extremely } \\
\text { high-risk of T1D }\end{array}$ & {$[10-13,20,72,73]$} \\
\hline Seroconversion to IAA & $\begin{array}{l}\text { Increased risk of T1D; association with young age at } \\
\text { seroconversion and increased risk of T1D; reverse } \\
\text { correlation between IAA levels and age at primary } \\
\text { seroconversion; association with HLA class II DR4-DQ8 } \\
\text { risk haplotypes }\end{array}$ & {$[7,18,20,74-79]$} \\
\hline GADA present at seroconversion & $\begin{array}{l}\text { Decreased risk of T1D in multiple autoantibody-positive } \\
\text { children; association with the slow progression to T1D; } \\
\text { association with protective HLA-DR3-DQ2 haplotype }\end{array}$ & {$[6,80-82]$} \\
\hline Seroconversion to ZnT8A in young age & $\begin{array}{l}\text { Delayed progression to T1D; no association with HLA } \\
\text { class I and II haplotypes }\end{array}$ & {$[68,80,83]$} \\
\hline Seroconversion to IA-2A & $\begin{array}{l}\text { Increased risk of T1D; association with the high-risk } \\
\text { DR4-DQ8 haplotype }\end{array}$ & {$[21,82,84-86]$} \\
\hline $\begin{array}{l}\text { High levels of IAA, IA-2A and GADA } \\
\text { autoantibodies at seroconversion }\end{array}$ & $\begin{array}{l}\text { Rapid progression from islet autoimmunity to the onset } \\
\text { of clinical T1D; increased risk of developing multiple } \\
\text { autoantibodies; accurate prediction of T1D }\end{array}$ & {$[7,12-14,20-23,74,87-90]$} \\
\hline $\begin{array}{l}\text { Dysregulation or functional deficiencies } \\
\text { of FOXP3-positive Treg }\end{array}$ & $\begin{array}{l}\text { Development of autoimmune diseases, including T1D; } \\
\text { more severe disease progression }\end{array}$ & [91-96] \\
\hline Serious life-threatening events and stress & Increased risk of T1D & [97-99] \\
\hline First-degree relatives & $\begin{array}{l}\text { Increased risk of T1D; more severe disease progression; } \\
\text { more frequent severe diabetic ketoacidosis and weight } \\
\text { loss in children with affected father }\end{array}$ & [100-102] \\
\hline C-section delivery & $\begin{array}{l}\text { Increased risk of T1D; reduced taxonomic and } \\
\text { functional diversity of gut microbiome }\end{array}$ & [103] \\
\hline Complicated vaginal delivery & Increased risk of T1D & {$[104]$} \\
\hline $\begin{array}{l}\text { Breastfeeding while introduction of the } \\
\text { new food }\end{array}$ & Decreased risk of T1D & [104] \\
\hline Short breastfeeding time & Increased risk of T1D & {$[105,106]$} \\
\hline $\begin{array}{l}\text { Early introduction of gluten-containing } \\
\text { solid foods; introduction of solid foods } \\
\text { early in life }\end{array}$ & Increased risk of islet autoimmunity & {$[104,107-110]$} \\
\hline $\begin{array}{l}\text { Fluctuations in the gut microbiome; high } \\
\text { Bacteroidetes / Firmicutes ratio; decreased } \\
\text { microflora diversity }\end{array}$ & $\begin{array}{l}\text { Increased risk of T1D; rapid development of islet cell } \\
\text { autoantibodies }\end{array}$ & [111-119] \\
\hline $\begin{array}{l}\text { Increased vitamin D consumption and } \\
\text { higher serum } 25 \text {-hydroxyvitamin D levels }\end{array}$ & Decreased risk of T1D & [120-123] \\
\hline
\end{tabular}


Table 1. Cont

\begin{tabular}{|c|c|c|}
\hline Risk and Protective Factors & Reported Effects and Associations & References \\
\hline $\begin{array}{l}\text { Coxsackie B virus, enteroviruses, and } \\
\text { rotaviruses }\end{array}$ & $\begin{array}{l}\text { Increased risk of T1D; rapid progression to T1D; } \\
\text { activation of the immune system; destruction of } \\
\text { pancreatic } \beta \text {-cells }\end{array}$ & [124-130] \\
\hline Measles, and influenza vaccinations & Decreased risk of T1D & {$[131,132]$} \\
\hline SARS-CoV-2 infection & Destruction of pancreatic $\beta$-cells & [133] \\
\hline $\begin{array}{l}\text { Early exposure to cow's milk, and high } \\
\text { consumption of cow's milk }\end{array}$ & Increased risk of T1D; rapid progression to T1D & [134-137] \\
\hline $\begin{array}{l}\text { Higher consumption of sugars and } \\
\text { carbohydrates }\end{array}$ & Increased risk of T1D; rapid progression to T1D & {$[138]$} \\
\hline $\begin{array}{l}\text { Higher birth weight and weight gain } \\
\text { during the first year of life }\end{array}$ & Increased risk of T1D & [139-142] \\
\hline Overweight, and obesity & $\begin{array}{l}\text { Increased risk of T1D; association with high-risk HLA } \\
\text { genotypes; increased risk of progression from islet } \\
\text { autoimmunity to type } 1 \text { diabetes and with development } \\
\text { of type } 1 \text { diabetes, but not with development of } \\
\text { autoantibodies }\end{array}$ & [143-147] \\
\hline
\end{tabular}

\section{Factors Affecting the Progression of Autoimmunity}

\subsection{Genetic Factors Associated with the HLA Region}

Although over 60 individual genetic loci have been associated with T1D in several studies [148-150], the polymorphisms of the HLA region remain the most significant contributors to the genetic susceptibility to T1D [151]. The HLA loci of DNA is approximately $4 \mathrm{Mb}$ long and contains over 200 identified genes. The HLA region genes that are involved in the autoimmune response and are known to be linked to the progression to T1D can be divided into two categories: three genes that encode class I $\alpha$-chain, (A, B and C), and three gene pairs of class II $\alpha$ - and $\beta$-chains (DR, DQ and DP) antigens. HLA class II loci are mapped to the centromeric end of the short arm of chromosome 6, while highly polymorphic class I loci are located at its telomeric end. Genes encoded by the class I HLA DR-DQ gene pairs can form four different types of class II molecules. The products of HLA class I and II loci genes are structurally similar molecules located on the cell surface, which function is the presentation of the peptide antigens to T lymphocytes. HLA class I antigens are responsible for CD8+ T cells presentation, while HLA class II antigens take part in a presentation to CD4+ T cells, which help B cell and CD8+ T cell responses. [152].

Although the HLA class II loci of chromosome 6 are highly polymorphic, different alleles are in strong linkage disequilibrium (LD) and form distinctive haplotypes. The HLA class II antigens combinations can form both protective $(\mathrm{OR}<1)$ and high-risk haplotypes [54]. The genetic risk of T1D is determined mainly by class II HLA DR-DQ haplotypes inherited from parents [153]. Polymorphisms in HLA-DRB1, DQA1 and DQB1 genes are strongly linked to T1D [154]. The two significant haplotypes associated with the risk of T1D are DR3-DQ2 and DR4-DQ8 [51]. The heterozygous DR3-DQ2/ DR4-DQ8 genotype is associated with the highest risk of progression from islet cell autoimmunity to clinical T1D [52]. Due to the strong LD, some haplotypes are inherited more often than others and might be overrepresented in specific populations. The risk-associated DR4-DQ8 and DR3-DQ2 are the most common haplotypes in Finland, partially explaining this population's high T1D incidence rate [53]. The HLA class II genotypes have been linked to the expansion of autoimmunity in children with both IAA- and GADA-initiated autoimmunity [5]. The frequencies of both susceptibility and protective DR-DQ haplotypes are changing in recent years. Due to the increasing contribution of environmental factors, especially in developed countries, protective and mild-risk HLA haplotypes appear more often in T1D children [155]. 
Three HLA class I antigens (HLA-A, -B and -C) are encoded as a single $\alpha$-chain. Several loci outside the HLA class II region have been associated with the increased risk of T1D $[55,156]$. Due to the strong LD of class I alleles and HLA class II loci, the exact association of class I antigens and progression to T1D was not easy in the past $[157,158]$. Independently from class II HLA, class I -A and -B alleles have been shown to play a crucial role in the age of onset of T1D [55-58]. Similarly, to the previous findings, in the Finnish population, polymorphisms of the HLA class I alleles have been linked to the age of onset of T1D and disease progression pace. HLA-B alleles are associated with increased T1D risk [159], suggesting that the HLA class I genes could play an essential role in the modulation of the $\beta$-cell destruction $[54,59,60]$.

\subsection{Genetic Factors Outside the HLA Region}

More than 40 loci outside the HLA region of chromosome 6 have been identified as modifiers of clinical T1D risk. The identification of novel non-HLA genetic risk factors was possible thanks to the large-scale genome-wide association studies (GWAS) performed in recent years [151,160-167].

The strongest genetic association between T1D and nucleotide polymorphisms has been reported in the promoter region of the gene coding for insulin (INS). The short repeated VNTR region within the INS gene is significantly associated with the disease progression [61,62]. Other loci associated with T1D were rs698 and rs3842753 SNPs within the INS gene [63-65]. The polymorphisms in the INS gene are associated with higher insulin expression in the pancreas, which may affect the tolerance to insulin by regulating the insulin mRNA and protein expression $[168,169]$.

Apart from the polymorphisms in the INS gene and few other loci: PTPN22, SLC30A8 [66], and $B A C H 2$ gene [16], no other SNP increase the risk of T1D with the odds ratio (OR) over 1.5. These findings highlight the importance of the HLA region compared to other genetic factors in the development of T1D [170]. Protein tyrosine phosphatase, non-receptor type 22 (PTPN22) gene polymorphism (rs2476601), is significantly associated with the progression from islet autoimmunity to clinical T1D [67] and rs45450798 in PTPN22 is affecting the $\beta$ cell destruction early after the initial seroconversion [16]. Substitutions in the PTPN22 gene that cause amino acid changes affect the B cells and T cells. In addition, it alters the function of immune cell signalling and impairs the function of regulatory $\mathrm{T}$ cells (Treg), which are essential in the pathogenesis of T1D [171,172]. Although most individual polymorphisms do not significantly predict the progression of autoimmunity, a genetic risk score (GRS) has been successfully applied to predict disease progression. GRS calculated as a weighted sum of all individual SNPs-associated risks has been reported to predict progression from islet autoimmunity to T1D in children and T1D progression pace in numerous studies [69-71]. Altogether, the genetic factors outside the HLA region and HLA genes are responsible for over $80 \%$ of the heritability of T1D [69,150].

\subsection{Islet Cell Autoantibodies}

Islet cell autoantibodies (any autoantibodies targeting the pancreatic islets of Langerhans) are some of the earliest markers of $\beta$-cell dysfunction. However, islet autoantibodies do not have any pathological functions [72]. Among biochemical autoantibodies, those targeting insulin (IAA), islet antigen 2 protein (IA-2A), glutamic acid decarboxylase (GADA) and zinc transporter 8 (ZnT8A) are the best characterised [4]. The non-specific islet cell cytoplasmic autoantibodies (ICA) are historically the first discovered [173,174].

The two most common autoantibodies present at seroconversion in childhood are IAA and GADA, whereas IA-2 and ZnT8 autoantibodies usually do not appear as the first one $[20,84,175]$. However, they are all common at the diagnosis of the disease $[5,6]$. The data obtained from longitudinal studies that have tracked populations from birth to the early onsets of clinical T1D indicate a high incidence of islet autoantibodies' appearance already during the first year of life [18,20,72,74]. In the DIPP study, IAA appeared most often as the first autoantibody at the age of two [20]. 
The age at seroconversion differs between various autoantibodies initialising autoimmunity. The peak is before the age of two years for IAA, whereas GADA peaks appears at the age of three to five years and continue to appear at a relatively high level throughout childhood [7-9]. Young age at autoantibody appearance increases the risk of T1D [12,18,20]. The risk of T1D increases significantly with an increasing number of positive autoantibodies [10-13,20,72]. Rapid multiple autoantibodies development is mainly linked to high disease risk [20,72,73].

The order of autoantibody appearance affects the disease risk [175]. In slow progressors to T1D, GADA is the most frequent islet autoantibody to appear as the first one $[80,81]$. In children positive for multiple autoantibodies, GADA-initiated autoimmunity has been associated with a reduced risk of progression to diabetes [82]. ZnT8A positivity at a young age has been associated with delayed progression to T1D [80]. However, children positive for IA-2A are at increased risk of the disease [82]. IA-2A autoantibodies are associated with a high risk of progression to clinical disease $[21,84,85]$. IAA frequently appears among the first autoantibodies or as the single autoantibody $[18,84,176,177]$. The association between young age at seroconversion for IAA and high risk of T1D is wellestablished [20,74,75]. Additionally, a strong reverse correlation between IAA levels and age at primary seroconversion has also been reported. IAA levels measured three months after seroconversion are decreasing significantly with increasing age at seroconversion, and in the case of GADA, the decrease in autoantibody level with time is less apparent. However, the age at seroconversion has not been reported to influence the levels of IA-2A as the first autoantibody [14,20-23,88].

The HLA-associated genetic risk affects both the number and levels of islet autoantibodies [178]. The HLA class II genotype has a very similar effect on the expansion of autoimmunity in children with IAA and GADA-initiated autoimmunity [5]. IAA autoantibodies measured at seroconversion are significantly associated with HLA class II DR4-DQ8 risk haplotype $[7,18,76-79]$ and polymorphisms of insulin-coding and PTPN22 genes [16,179-182]. Similarly, IA-2A levels are significantly associated with the high-risk DR4-DQ8 haplotype [86]. GADA levels measured after seroconversion are significantly associated with the genetic risk of HLA class II genotypes [53]. Moreover, GADA autoantibodies appear significantly more often at seroconversion in children with HLA-DR3-DQ2 haplotype [6]. ZnT8A is associated with the accumulation of insulin [83]. No significant associations between HLA class I and II genotypes and persistent ZnT8A development have been reported. However, polymorphisms in the ZnT8 protein-coding SLC30A8 gene, which affects insulin production, have been reported to be associated with T1D [68].

The progression from islet autoimmunity to the onset of clinical T1D is associated with higher levels of IAA [12,20], IA-2A [7,20,21,87,88] and also GADA [13,23]. Although, in the TEDDY study, GADA levels did not increase the risk of T1D [87]. The observed risk of T1D is time-constant for high IA-2A levels but decrease over time for IAA and GADA [14]. In recent studies, the levels of biochemical autoantibodies have been reported to be significantly higher in children who later progressed to T1D compared to nonprogressors $[14,20-23,88]$. The autoantibody levels rise for the first year after autoantibody appearance in children who progress to diabetes or multiple autoantibodies after initial seroconversion. One year after the initial seroconversion, autoantibody levels are levelling off or declining, especially in the case of IAA. In the TrialNet study, high GADA levels were significantly associated with the overall risk of developing multiple autoantibodies [22,89]. Other studies have also reported that the levels of islet autoantibodies can be used for accurate T1D prediction $[21,74,90]$.

\subsection{Autoreactive and Regulatory T Cells}

Although islet cell autoantibodies are the primary markers of progression of the disease progression, autoantibodies alone do not affect the $\beta$-cell damage [100]. T1D is caused by autoreactive T cells that activate and kill the $\beta$-cells in the pancreas, resulting in insulin insufficiency and hyperglycaemia. According to the recent findings, the un- 
controlled activation and expansion of autoreactive CD4+ and CD8+ T cells in T1D are caused by the defects in immunosuppressive regulatory $\mathrm{T}$ cells (Treg), which can suppress activated autoreactive cells. In heath, potentially pathogenic autoreactive $\mathrm{T}$ cells, with specificity for islet autoantigens, are held in check by multiple regulatory mechanisms, including Tregs. Tregs are a specialized subpopulation of $\mathrm{T}$ cells that maintain homeostasis and self-tolerance by suppressing immune response [91]. Since the precise differentiation between subsets of regulatory cells in humans is not trivial, transcription factor forkhead box P3 (FOXP3) Tregs term is often used to refer to both Tregs generated from a subset of CD4+ in the thymus, as well as Tregs generated from the naïve CD4+CD25- T cells in the periphery [92]. Both subsets of FOXP3-positive Tregs can inhibit and downregulate effector $\mathrm{T}$ cell proliferation and cytokine production and play a critical role in preventing autoimmunity $[183,184]$. Repairing the defects in Treg in order to restore the defects in immune system regulation is a potential strategy for disease treatment [185].

Autoreactive $\mathrm{T}$ cells are the primary mediators that are likely to contribute to the pathogenesis of T1D [186]. T-cell subsets might be useful as biomarkers of treatment efficacy in clinical trials [187]. Thelper cells are increased in number before and at diagnosis of type 1 diabetes and might be helpful as biomarkers for disease prediction $[188,189]$. The most specific markers of Treg cells are FOXP3, CD4 and CD25. Alterations in CD4 T cells have been reported in patients with T1D. Similarly, the frequency of T helper cells has been reported to be increased in multiple autoantibody-positive children [190-192]. Dysregulation in Treg cells frequencies or functions may lead to the development of autoimmune diseases, including T1D [92,93]. Functional deficiencies of Treg in T1D are associated with T1D progression [94]. Changes in subsets of Treg might be related to more advanced stages of T1D progression [93]. Alterations in Treg profiles lead to the dysfunction of the immune regulatory mechanisms critical for protection from T1Dassociated autoimmunity. FOXP3 is necessary for the proper function of Treg, and their dysfunction might lead to immunodysregulation polyendocrinopathy enteropathy $X$ linked syndrome, which is often characterized by autoimmune enteropathy and T1D [193]. Alterations in FOXP3 Treg profiles have been associated with T1D and might serve as the potential biomarkers of the disease progression $[91,95,96]$.

\subsection{Environmental Risk Factors}

In T1D, various environmental factors can result in the progressive loss of $\beta$-cell function that manifests clinically as hyperglycaemia. T1D is an autoimmune disease caused by an interplay of genetic and environmental factors. Several genetic risk and protective factors, mainly associated with the HLA genotypes, have been identified using genomewide association studies during the past decades. It was speculated that the genetic predispositions of an individual solely drive the progression of autoimmunity. However, genetic predisposition alone is not sufficient to explain the increase in the prevalence of T1D since the 1950s. Several hypotheses propose an explanation for the rise in the prevalence of T1D [194-196]. Additional environmental factors explain the increase in frequencies of class II HLA genotypes in the general population in recent years [197,198].

Having first-degree relatives affected by T1D increases the risk of the disease compared with the more often sporadic cases of T1D. Children with familiar disease have IAA autoantibodies appearing more frequently than children with sporadic T1D [100,101]. Interestingly, having an affected father compared to an affected mother is linked to more frequent severe diabetic ketoacidosis and weight loss in children affected by T1D. Paternal T1D is associated with more severe disease progression [102].

Environmental factors, mainly those associated with changes in the gut microbiome, are a key modulator of T1D, though its precise role in the progression of autoimmunity is unclear [111,112]. Living environment, microbial contact, and taxonomic and functional changes in the gut microbiome of diabetic patients have been of interest in recent years, especially the association between the gut microbiome and immune system and the pathogenesis of T1D. 


\subsection{Gut Microflora}

The gut microbiome can be affected by multiple factors while simultaneously maintaining its homeostasis. At childbirth, the gut microbiome of infants is largely dependent on the delivery method, and there are significant differences between the infants delivered through C-section and vaginally delivered. In infants born through C-section, the gut microflora is similar to the mother's skin surface microflora. In contrast, in those vaginally delivered, it is closer to the mother's vaginal microbiome [199]. Infants delivered through the $\mathrm{C}$-section were also associated with reduced taxonomic and functional diversity of its gut microbiome [103].

During the first years after childbirth, a child's immune system gains sufficient immunological memory by intense education through numerous microbial contacts and infections. It is the period when the gut microbiome depends mainly on diet, drugs, antibiotics usage and even emotional stress. Serious life-threatening events and childhood emotional stress is associated with a higher risk of T1D in children [97-99]. Some of the other known factors that affect the diversity of infants' gut microbiome are breastfeeding time, presence of solid foods in the early diet and introduction of antibiotics [200]. In addition, breastfeeding while introducing solid foods has been reported to decrease the risk of T1D [104]. The composition of the child gut microflora stabilises by the age of three and afterwards behaves similarly to this in adults [201]. Maturation of the gut microbiome coincides with the development of an immune system and the appearance of the first autoantibodies associated with T1D [202].

Changes in the taxonomic composition of the gut microbiome precede the appearance of islet autoimmunity [203]. These taxonomic changes in the gut microbiome composition result in the decreased diversity of gut microbes in T1D. Children that are positive for at least one islet cell autoantibody and those who later during the follow-up progress to T1D have a higher Bacteroidetes/Firmicutes ratio and lower Shannon diversity index of the gut microbiome compared to the healthy individuals $[113,114]$. Similarly, decreased diversity of gut microflora was observed when autoantibody-positive children before and after the onset of clinical T1D were compared [115]. A higher abundance of Bacteroides is common in children positive for at least one islet cell autoantibody [116], and progressors to T1D $[117,118]$. Data coming from the longitude follow-up studies demonstrate that alterations in the gut microbiome, which can be independently affected by multiple factors, are associated with the early development of islet cell autoantibodies [119]. It is being speculated that chronic fluctuating changes in the taxonomic composition of gut microflora could lead to system dysregulation and trigger immune responses, which lead to the progression to autoimmunity. However, this hypothesis has not been confirmed.

\subsection{Viral Infections}

Several pathogens, especially viruses, may be involved in the progression of autoimmunity and T1D development. Some studies have shown that viral infections, mainly those by enteroviruses, could be involved in the pathogenesis of T1D. Because of the molecular mimicry of human islet cell autoantigens, Coxsackie B virus and enteroviruses, which could be found in the pancreatic islets of most patients with T1D, could speed up the disease progression through the activation of the immune system [124-127]. The enteroviruses may also cause an acute infection of the pancreatic $\beta$-cells, resulting in $\beta$-cell destruction and progression to clinical T1D [128].

Several epidemiological studies supported the role of viruses, other than enteroviruses, especially rotaviruses $[129,130]$, in progression to clinical T1D. An increased risk of disease progression in children affected with rotaviruses stays in line with the recent findings in the USA and Australian populations. In these two countries, a decrease in the prevalence of T1D was observed shortly after rotavirus vaccinations recommendations were introduced $[129,130]$. The association between the decreased T1D risk and other vaccinations have been reported [204] especially in the context of measles vaccination. The risk of 
T1D is significantly lower in measles vaccinated children [131]. Similarly, the influenza vaccination was associated with lower T1D risk in the TEDDY study [132].

During the COVID-19 pandemic of 2020, several studies have investigated the potential association between the severe acute respiratory syndrome coronavirus 2 (SARS-CoV-2) infection and the prevalence of T1D in children and progression to diabetic ketoacidosis [205-211]. The evidence for the insulin-producing $\beta$-cell damage by the virus has been reported [133].

\subsection{Dietary Factors}

Diet is another environmental factor that affects the progression from islet autoimmunity to clinical T1D. Early exposure to cow's milk is associated with more rapid progression to T1D. One hypothesis explaining the role of cow's milk in disease progression is albumin's molecular mimicry to ICA, a surface protein of pancreatic $\beta$-cells [134]. High consumption of cow's milk in childhood has been associated with an increased risk of progression from islet autoimmunity to T1D [135-137]. The effect of hydrolysed infant formula versus conventional formula on the risk of T1D was studied in the TRIGR Randomized Clinical Trial [212]. However, no effect of the hydrolysed infant formula consumption on the risk of T1D was found.

An increase in the prevalence of T1D since the 1950s is often linked to Western civilisations' diet and eating habits. Changes in children's eating habits include early exposure to processed food, the introduction of gluten-containing food and cow's milk, short breastfeeding and formula feeding. These dietary changes may partially explain a recent increase in diabetes prevalence in developed and developing countries compared to the rest of the world. Higher consumption of sugars and carbohydrates have been associated with more rapid progression of T1D in the DAISY follow-up study in 2015 [138].

The studies of potential dietary contributors to T1D were primarily focused on the infancy period. Still, it has been shown in several studies that maternal diet during pregnancy and the breastfeeding period may also influence the progression of islet cell autoimmunity. Short breastfeeding time is associated with an increased risk of progression of autoimmunity $[105,106]$. Early introduction of gluten-containing solid foods is associated with an increased risk of islet cell autoimmunity [107-110]. Interestingly, early exposure to gluten-free oats increases the risk of T1D in a similar fashion [213]. Children exposed to gluten-containing cereals, which were simultaneously breastfed, were less likely to progress to T1D, which emphasise breast milk's role in early immune system development [104].

Birth weight and weight gain during the first year of life are associated with the risk of T1D [139]. Low birth weight has been associated with decreased risk of T1D, and an increased weight gain in infancy has been associated with an increased risk of T1D [140-142]. The prevalence of obesity has been linked to the increased risk of T1D in DiMe children [143]. In more recent studies, a significant association between body weight and selected HLA genotypes and progression of islet autoimmunity has been reported [144-146]. In children under the age of 10, overweight has been reported to be positively associated with an increased risk of progression from islet autoimmunity to type 1 diabetes and with the development of type 1 diabetes, but not with the development of autoantibodies [147].

Increased vitamin D consumption and higher serum 25-hydroxyvitamin D levels are considered protective factors against T1D [120,121]. The deficiency of vitamin D may increase the risk of the disease [122,123]. However, in the longitudinal follow-up DIPP study, no association has been found between cord blood 25- hydroxyvitamin D concentrations and islet autoantibodies development and progression to T1D [214,215]. No association of vitamin D intake and islet autoimmunity was also reported in the DAISY study [216]. 


\section{Conclusions}

The disease progression factors after the diagnosis are not fully understood, and the process has been proven highly heterogeneous. In addition to the well-established factors, including supplementary cow's milk formula feeding, milk consumption, viral infections and alteration in the gut microflora, numerous environmental, social, and economic factors can affect the pathogenesis of this disease in children. The gene-environmental interactions exist, and the underlying causes of T1D are complex and multifactorial (Table 1).

The increase in the prevalence of T1D in recent years emphasises the need for new, reliable, and cost-effective disease prediction methods. To date, the individuals at high T1D risk can already be identified reliably by HLA risk genotypes screening and islet autoantibodies profiling. These two screening methods are the most reliable strategies for the prediction of T1D. Screening for HLA high-risk genotypes is easily accessible in all cases. However, islet cell autoantibodies can only be measured at a certain stage of disease progression, at which the humoral autoimmunity has already been engaged. Thus, novel approaches besides traditional screening methods are required to predict the disease onset accurately, before the first signs of islet cell autoantibodies appear. Changes in the taxonomic composition of the gut microbiome, which are currently studied in children as potential biomarkers of T1D, precede the appearance of islet autoimmunity

Identifying factors leading to the destruction of $\beta$-cells offers potential means for intervention aimed at preventing T1D. It is already possible to manipulate the spontaneous appearance of islet autoantibodies by dietary modification early in life. Other attractive therapeutic targets for T1D treatment are Tregs, of which low number and impaired functionality are characteristic already at the disease onset. A transfer of ex vivo expanded Tregs back to the patient might be a potential approach in T1D treatment. This innovative approach is supported by the early evidence coming from clinical trials in kidney transplantation [217-219]. T1D causes an overwhelming burden on the families of affected children and puts a strain on the healthcare system. Children affected with T1D have increased mortality as well as increased risk of cardiovascular comorbidity, but thanks to an early diagnosis, complications at disease onset may be decreased.

Author Contributions: Conceptualization, W.B. and A.G.; investigation, W.B.; writing-original draft preparation, W.B.; writing-review and editing, W.B., A.G. and A.K.; supervision, A.K. All authors have read and agreed to the published version of the manuscript.

Funding: A.G. was supported by the grants GINOP-2.3.4-15-2020-00010, GINOP-2.3.1-20-2020-00001 and Educating Experts of the Future: Developing Bioinformatics and Biostatistics competencies of European Biomedical Students (BECOMING, 2019-1-HU01-KA203-061251). Bioinformatics infrastructure was supported by ELIXIR Hungary (http:/ / elixir-hungary.org/, (accessed on 16 June 2021).

Acknowledgments: We thank all the participating families, and the personnel of the cited longitudinal follow-up studies.

Conflicts of Interest: The authors declare no conflict of interest.

\section{Abbreviations}

$\begin{array}{ll}\text { ABIS } & \text { All Babies in Southeast Sweden; } \\ \text { ADA } & \text { American Diabetes Association; } \\ \text { BACH2 } & \text { BTB Domain and CNC Homolog 2; } \\ \text { COVID-19 } & \text { Coronavirus disease 2019; } \\ \text { DAISY } & \text { Diabetes Autoimmunity Study in the Young; } \\ \text { DiMe } & \text { Childhood Diabetes in Finland; } \\ \text { DiPiS } & \text { Diabetes Prediction in Skåne; } \\ \text { DIPP } & \text { The Finnish Type 1 Diabetes Prediction and Prevention; } \\ \text { FOXP3 } & \text { Transcription factor forkhead box P3; } \\ \text { GADA } & \text { Autoantibodies to glutamic acid decarboxylase; }\end{array}$




$\begin{array}{ll}\text { GRS } & \text { Genetic risk score; } \\ \text { HLA } & \text { Human leukocyte antigen; } \\ \text { HR } & \text { Hazard ratio; } \\ \text { IA-2A } & \text { Autoantibodies to islet antigen-2; } \\ \text { IAA } & \text { Autoantibodies to insulin; } \\ \text { ICA } & \text { Islet cells antibody; } \\ \text { INS } & \text { Insulin gene; } \\ \text { VNTR } & \text { Variable number of tandem repeats; } \\ \text { INSPAD } & \text { International Society for Pediatric and Adolescent Diabetes; } \\ \text { OGTT } & \text { Oral glucose tolerance test; } \\ \text { OR } & \text { Odds ratio; } \\ \text { PTPN22 } & \text { Protein tyrosine phosphatase, non-receptor type 22 gene; } \\ \text { SARS-CoV-2 } & \text { Severe acute respiratory syndrome coronavirus 2; } \\ \text { SLC30A8 } & \text { Solute Carrier Family 30 Member 8; } \\ \text { SNP } & \text { Single nucleotide polymorphism; } \\ \text { TEDDY } & \text { The Environmental Determinants of Diabetes in the Young; } \\ \text { T1D } & \text { Type 1 diabetes; } \\ \text { Treg } & \text { Regulatory T Cell; } \\ \text { ZnT8A } & \text { Autoantibodies to zinc transporter 8 }\end{array}$

\section{References}

1. Atkinson, M.A.; Eisenbarth, G.S.; Michels, A.W. Type 1 diabetes. Lancet 2014, 383, 69-82. [CrossRef]

2. Paschou, S.A.; Papadopoulou-Marketou, N.; Chrousos, G.P.; Kanaka-Gantenbein, C. On type 1 diabetes mellitus pathogenesis. Endocr. Connect. 2018, 7, R38-R46. [CrossRef]

3. Battaglia, M.; Ahmed, S.; Anderson, M.S.; Atkinson, M.A.; Becker, D.; Bingley, P.J.; Bosi, E.; Brusko, T.M.; DiMeglio, L.A.; Evans-Molina, C.; et al. Introducing the Endotype Concept to Address the Challenge of Disease Heterogeneity in Type 1 Diabetes. Diabetes Care 2020, 43, 5-12. [CrossRef] [PubMed]

4. Sosenko, J.M. Staging the progression to type 1 diabetes with prediagnostic markers. Curr. Opin. Endocrinol. Diabetes Obes. 2016, 23, 297-305. [CrossRef]

5. Bauer, W.; Veijola, R.; Lempainen, J.; Kiviniemi, M.; Härkönen, T.; Toppari, J.; Knip, M.; Gyenesei, A.; Ilonen, J. Age at Seroconversion, HLA Genotype, and Specificity of Autoantibodies in Progression of Islet Autoimmunity in Childhood. J. Clin. Endocrinol. Metab. 2019, 104, 4521-4530. [CrossRef]

6. $\quad$ Ilonen, J.; Lempainen, J.; Hammais, A.; Laine, A.P.; Härkönen, T.; Toppari, J.; Veijola, R.; Knip, M. Primary islet autoantibody at initial seroconversion and autoantibodies at diagnosis of type 1 diabetes as markers of disease heterogeneity. Pediatr. Diabetes 2018, 19, 284-292. [CrossRef]

7. Ilonen, J.; Hammais, A.; Laine, A.-P.; Lempainen, J.; Vaarala, O.; Veijola, R.; Simell, O.; Knip, M. Patterns of $\beta$-cell autoantibody appearance and genetic associations during the first years of life. Diabetes 2013, 62, 3636-3640. [CrossRef] [PubMed]

8. Giannopoulou, E.Z.; Winkler, C.; Chmiel, R.; Matzke, C.; Scholz, M.; Beyerlein, A.; Achenbach, P.; Bonifacio, E.; Ziegler, A.-G. Islet autoantibody phenotypes and incidence in children at increased risk for type 1 diabetes. Diabetologia 2015, 58, 2317-2323. [CrossRef]

9. Krischer, J.P.; Lynch, K.F.; Lernmark, Å.; Hagopian, W.A.; Rewers, M.J.; She, J.-X.; Toppari, J.; Ziegler, A.-G.; Akolkar, B. Genetic and Environmental Interactions Modify the Risk of Diabetes-Related Autoimmunity by 6 Years of Age: The TEDDY Study. Diabetes Care 2017, 40, 1194-1202. [CrossRef]

10. Kukko, M.; Kimpimäki, T.; Korhonen, S.; Kupila, A.; Simell, S.; Veijola, R.; Simell, T.; Ilonen, J.; Simell, O.; Knip, M. Dynamics of diabetes-associated autoantibodies in young children with human leukocyte antigen-conferred risk of type 1 diabetes recruited from the general population. J. Clin. Endocrinol. Metab. 2005, 90, 2712-2717. [CrossRef]

11. Verge, C.F.; Gianani, R.; Kawasaki, E.; Yu, L.; Pietropaolo, M.; Chase, H.P.; Eisenbarth, G.S. Number of autoantibodies (against insulin, GAD or ICA512/IA2) rather than particular autoantibody specificities determines risk of type I diabetes. J. Autoimmun. 1996, 9, 379-383. [CrossRef]

12. Siljander, H.T.A.; Simell, S.; Hekkala, A.; Lähde, J.; Simell, T.; Vähäsalo, P.; Veijola, R.; Ilonen, J.; Simell, O.; Knip, M. Predictive characteristics of diabetes-associated autoantibodies among children with HLA-conferred disease susceptibility in the general population. Diabetes 2009, 58, 2835-2842. [CrossRef] [PubMed]

13. Bingley, P.J.; Gale, E.A.M. Progression to type 1 diabetes in islet cell antibody-positive relatives in the European Nicotinamide Diabetes Intervention Trial: The role of additional immune, genetic and metabolic markers of risk. Diabetologia 2006, 49, 881-890. [CrossRef]

14. Köhler, M.; Beyerlein, A.; Vehik, K.; Greven, S.; Umlauf, N.; Lernmark, Å.; Hagopian, W.A.; Rewers, M.; She, J.X.; Toppari, J.; et al. Joint modeling of longitudinal autoantibody patterns and progression to type 1 diabetes: Results from the TEDDY study. Acta Diabetol. 2017, 54, 1009-1017. [CrossRef]

15. Pociot, F.; Lernmark, Å. Genetic risk factors for type 1 diabetes. Lancet 2016, 387, 2331-2339. [CrossRef] 
16. Lempainen, J.; Laine, A.-P.; Hammais, A.; Toppari, J.; Simell, O.; Veijola, R.; Knip, M.; Ilonen, J. Non-HLA gene effects on the disease process of type 1 diabetes: From HLA susceptibility to overt disease. J. Autoimmun. 2015, 61, 45-53. [CrossRef]

17. Turtinen, M.; Härkönen, T.; Parkkola, A.; Ilonen, J.; Knip, M. Sex as a determinant of type 1 diabetes at diagnosis. Pediatric Diabetes 2018, 19, 1221-1228. [CrossRef]

18. Krischer, J.P.; Lynch, K.F.; Schatz, D.A.; Ilonen, J.; Lernmark, Å.; Hagopian, W.A.; Rewers, M.J.; She, J.-X.; Simell, O.G.; Toppari, J.; et al. The 6 year incidence of diabetes-associated autoantibodies in genetically at-risk children: The TEDDY study. Diabetologia 2015, 58, 980-987. [CrossRef]

19. Regnell, S.E.; Lernmark, Å. Early prediction of autoimmune (type 1) diabetes. Diabetologia 2017, 60, 1370-1381. [CrossRef] [PubMed]

20. Parikka, V.; Näntö-Salonen, K.; Saarinen, M.; Simell, T.; Ilonen, J.; Hyöty, H.; Veijola, R.; Knip, M.; Simell, O. Early Seroconversion and rapidly increasing autoantibody concentrations predict prepubertal manifestation of type 1 diabetes in Children at genetic risk. Diabetologia 2012, 55, 1926-1936. [CrossRef] [PubMed]

21. Achenbach, P.; Warncke, K.; Reiter, J.; Naserke, H.E.; Williams, A.J.K.; Bingley, P.J.; Bonifacio, E.; Ziegler, A.G. Stratification of Type 1 Diabetes Risk on the Basis of Islet Autoantibody Characteristics. Diabetes 2004, 53, 384-392. [CrossRef]

22. Bingley, P.J.; Boulware, D.C.; Krischer, J.P. The implications of autoantibodies to a single islet antigen in relatives with normal glucose tolerance: Development of other autoantibodies and progression to type 1 diabetes. Diabetologia 2016, 59, 542-549. [CrossRef]

23. Mayr, A.; Schlosser, M.; Grober, N.; Kenk, H.; Ziegler, A.G.; Bonifacio, E.; Achenbach, P. GAD autoantibody affinity and epitope specificity identify distinct immunization profiles in children at risk for type 1 diabetes. Diabetes 2007, 56, 1527-1533. [CrossRef] [PubMed]

24. Bruno, G.; Gruden, G.; Songini, M. Incidence of type 1 diabetes in age groups above 15 years: Facts, hypothesis and prospects for future epidemiologic research. Acta Diabetol. 2016, 53, 339-347. [CrossRef]

25. Rawshani, A.; Landin-Olsson, M.; Svensson, A.-M.; Nyström, L.; Arnqvist, H.J.; Bolinder, J.; Gudbjörnsdottir, S. The incidence of diabetes among 0-34 year olds in Sweden: New data and better methods. Diabetologia 2014, 57, 1375-1381. [CrossRef] [PubMed]

26. Oram, R.A.; Sims, E.K.; Evans-Molina, C. Beta cells in type 1 diabetes: Mass and function; sleeping or dead? Diabetologia 2019, 62, 567-577. [CrossRef] [PubMed]

27. Gale, E.A.M. The rise of childhood type 1 diabetes in the 20th century. Diabetes 2002, 51, 3353-3361. [CrossRef]

28. Patterson, C.C.; Harjutsalo, V.; Rosenbauer, J.; Neu, A.; Cinek, O.; Skrivarhaug, T.; Rami-Merhar, B.; Soltesz, G.; Svensson, J.; Parslow, R.C.; et al. Trends and cyclical variation in the incidence of childhood type 1 diabetes in 26 European centres in the 25 year period 1989-2013: A multicentre prospective registration study. Diabetologia 2019, 62, 408-417. [CrossRef] [PubMed]

29. Parviainen, A.; But, A.; Siljander, H.; Knip, M. Decreased incidence of type 1 diabetes in young finnish children. Diabetes Care 2020, 43, 2953-2958. [CrossRef]

30. Morgan, E.; Cardwell, C.R.; Black, C.J.; McCance, D.R.; Patterson, C.C. Excess mortality in Type 1 diabetes diagnosed in childhood and adolescence: A systematic review of population-based cohorts. Acta Diabetol. 2015, 52, 801-807. [CrossRef] [PubMed]

31. Rawshani, A.; Sattar, N.; Franzén, S.; Rawshani, A.; Hattersley, A.T.; Svensson, A.-M.; Eliasson, B.; Gudbjörnsdottir, S. Excess mortality and cardiovascular disease in young adults with type 1 diabetes in relation to age at onset: A nationwide, register-based cohort study. Lancet 2018, 392, 477-486. [CrossRef]

32. Hekkala, A.M.; Ilonen, J.; Toppari, J.; Knip, M.; Veijola, R. Ketoacidosis at diagnosis of type 1 diabetes: Effect of prospective studies with newborn genetic screening and follow up of risk children. Pediatric Diabetes 2018, 19, 314-319. [CrossRef]

33. Steck, A.K.; Larsson, H.E.; Liu, X.; Veijola, R.; Toppari, J.; Hagopian, W.A.; Haller, M.J.; Ahmed, S.; Akolkar, B.; Lernmark, Å.; et al . Residual beta-cell function in diabetes children followed and diagnosed in the TEDDY study compared to community controls. Pediatric Diabetes 2017, 18, 794-802. [CrossRef] [PubMed]

34. American Diabetes Association. 2. Classification and diagnosis of diabetes: Standards of medical care in diabetes-2021. Diabetes Care 2021, 44, S15-S33. [CrossRef]

35. Van Belle, T.L.; Coppieters, K.T.; Von Herrath, M.G. Type 1 diabetes: Etiology, immunology, and therapeutic strategies. Physiol. Rev. 2011, 91, 79-118. [CrossRef] [PubMed]

36. DiMeglio, L.A.; Carmella Evans-Molina, R.A.O. Type 1 Diabetes. HHS Public Access. Physiol. Behav. 2019, 176, 139-148. [CrossRef]

37. Xie, Z.; Chang, C.; Zhou, Z. Molecular Mechanisms in Autoimmune Type 1 Diabetes: A Critical Review. Clin. Rev. Allergy Immunol. 2014, 47, 174-192. [CrossRef] [PubMed]

38. Bronstein, J.; Lawrence, R.D. Two types of diabetes mellitus, with and without available plasma insulin. Br. Med. J. 1951, 1, 732-734. [CrossRef]

39. Mayer-Davis, E.J.; Kahkoska, A.R.; Jefferies, C.; Dabelea, D.; Balde, N.; Gong, C.X.; Aschner, P.; Craig, M.E. ISPAD Clinical Practice Consensus Guidelines 2018: Definition, epidemiology, and classification of diabetes in children and adolescents. Pediatric Diabetes 2018, 19, 7-19. [CrossRef]

40. International Diabetes Federation IDF. Diabetes Atlas, 9th ed.; International Diabetes Federation IDF: Brussels, Belgium, 2019.

41. Patterson, C.C.; Dahlquist, G.G.; Gyürüs, E.; Green, A.; Soltész, G. Incidence trends for childhood type 1 diabetes in Europe during 1989-2003 and predicted new cases 2005-20: A multicentre prospective registration study. Lancet 2009, 373, 2027-2033. [CrossRef] 
42. Sussman, M.; Benner, J.; Haller, M.J.; Rewers, M.; Griffiths, R. Estimated Lifetime Economic Burden of Type 1 Diabetes. Diabetes Technol. Ther. 2020, 22, 121-130. [CrossRef] [PubMed]

43. Ludvigsson, J.; Ludvigsson, M.; Sepa, A. Screening for prediabetes in the general child population: Maternal attitude to participation. Pediatric Diabetes 2001, 2, 170-174. [CrossRef] [PubMed]

44. Ilonen, J.; Reijonen, H.; Herva, E.; Sjöroos, M.; Iitiä, A.; Lövgren, T.; Veijola, R.; Knip, M.; Åkerblom, H.K. Rapid HLA-DQB1 genotyping for four alleles in the assessment of risk for IDDM in the Finnish population. Diabetes Care 1996, 19, 795-800. [CrossRef] [PubMed]

45. Rewers, M.; She, J.X.; Ziegler, A.G.; Simell, O.G.; Lernmark, Å.; Hagopian, W.A.; Krischer, J.P.; Akolkar, B. The environmental determinants of diabetes in the young (TEDDY) study. Ann. N. Y. Acad. Sci. 2008, 1150, 1-13. [CrossRef]

46. Lernmark, B.; Elding-Larsson, H.; Hansson, G.; Lindberg, B.; Lynch, K.; Sjöblad, S. Parent responses to participation in genetic screening for diabetes risk. Pediatric Diabetes 2004, 5, 174-181. [CrossRef]

47. Rewers, M.; Bugawan, T.L.; Norris, J.M.; Blair, A.; Beaty, B.; Hoffman, M.; McDuffie, R.S.; Hamman, R.F.; Klingensmith, G.; Eisenbarth, G.S.; et al. Newborn screening for HLA markers associated with IDDM: Diabetes autoimmunity study in the young (DAISY). Diabetologia 1996, 39, 807-812. [CrossRef]

48. Hummel, S.; Ziegler, A.G. Early determinants of type 1 diabetes: Experience from the BABYDIAB and BABYDIET studies. Am. $J$ Clin. Nutr. 2011, 94, 1821S-1823S. [CrossRef]

49. Mahon, J.L.; Sosenko, J.M.; Rafkin-Mervis, L.; Krause-Steinrauf, H.; Lachin, J.M.; Thompson, C.; Bingley, P.J.; Bonifacio, E.; Palmer, J.P.; Eisenbarth, G.S.; et al. The TrialNet natural history study of the development of type 1 diabetes: Objectives, design, and initial results. Pediatric Diabetes 2009, 10, 97-104. [CrossRef]

50. Tuomilehto, J.; Lounamaa, R.; Tuomilehto-Wolf, E.; Reunanen, A.; Virtala, E.; Kaprio, E.A.; Åkerblom, H.K.; Toivanen, L.; Fagerlund, A.; Flittner, M.; et al. Epidemiology of childhood diabetes mellitus in Finland-Background of a nationwide study of Type 1 (insulin-dependent) diabetes mellitus. Diabetologia 1992, 35, 70-76. [CrossRef]

51. Aly, T.A.; Ide, A.; Jahromi, M.M.; Barker, J.M.; Fernando, M.S.; Babu, S.R.; Yu, L.; Miao, D.; Erlich, H.A.; Fain, P.R.; et al. Extreme genetic risk for type 1A diabetes. Proc. Natl. Acad. Sci. USA 2006, 103, 14074-14079. [CrossRef]

52. Noble, J.A.; Valdes, A.M. Genetics of the HLA region in the prediction of type 1 diabetes. Curr. Diabetes Rep. 2011, 11, 533-542. [CrossRef]

53. Hermann, R.; Turpeinen, H.; Laine, A.P.; Veijola, R.; Knip, M.; Simell, O.; Sipilä, I.; Akerblom, H.K.; Ilonen, J. HLA DR-DQencoded genetic determinants of childhood-onset type 1 diabetes in Finland: An analysis of 622 nuclear families. Tissue Antigens 2003, 62, 162-169. [CrossRef]

54. Ilonen, J.; Kiviniemi, M.; Lempainen, J.; Simell, O.; Toppari, J.; Veijola, R.; Knip, M. Genetic susceptibility to type 1 diabetes in childhood-Estimation of HLA class II associated disease risk and class II effect in various phases of islet autoimmunity. Pediatric Diabetes 2016, 17, 8-16. [CrossRef] [PubMed]

55. Noble, J.A.; Valdes, A.M.; Varney, M.D.; Carlson, J.A.; Moonsamy, P.; Fear, A.L.; Lane, J.A.; Lavant, E.; Rappner, R.; Louey, A.; et al. HLA class I and genetic susceptibility to type 1 diabetes: Results from the Type 1 Diabetes Genetics Consortium. Diabetes 2010, 59, 2972-2979. [CrossRef] [PubMed]

56. Tait, B.D.; Colman, P.G.; Morahan, G.; Marchinovska, L.; Dore, E.; Gellert, S.; Honeyman, M.C.; Stephen, K.; Loth, A. HLA genes associated with autoimmunity and progression to disease in type 1 diabetes. Tissue Antigens 2003, 61, 146-153. [CrossRef]

57. Valdes, A.M.; Erlich, H.A.; Noble, J.A. Human leukocyte antigen class I B and C loci contribute to Type 1 Diabetes (T1D) susceptibility and age at T1D onset. Hum. Immunol. 2005, 66, 301-313. [CrossRef] [PubMed]

58. Noble, J.A.; Valdes, A.M.; Bugawan, T.L.; Apple, R.J.; Thomson, G.; Erlich, H.A. The HLA class I A locus affects susceptibility to type 1 diabetes. Hum. Immunol. 2002, 63, 657-664. [CrossRef]

59. Mbunwe, E.; Van Der Auwera, B.J.; Weets, I.; Van Crombrugge, P.; Crenier, L.; Coeckelberghs, M.; Seret, N.; Decochez, K.; Vandemeulebroucke, E.; Gillard, P.; et al. In antibody-positive first-degree relatives of patients with type 1 diabetes, HLA-A*24 and HLA-B*18, but not HLA-*39, are predictors of impending diabetes with distinct HLA-DQ interactions. Diabetologia 2013, 56, 1964-1970. [CrossRef]

60. Lipponen, K.; Gombos, Z.; Kiviniemi, M.; Siljander, H.; Lempainen, J.; Hermann, R.; Veijola, R.; Simell, O.; Knip, M.; Ilonen, J. Effect of HLA class I and class II alleles on progression from autoantibody positivity to overt type 1 diabetes in children with risk-associated class II genotypes. Diabetes 2010, 59, 3253-3256. [CrossRef] [PubMed]

61. Bell, G.I.; Horita, S.; Karam, J.H. A polymorphic locus near the human insulin gene is associated with insulin-dependent diabetes mellitus. Diabetes 1984, 33, 176-183. [CrossRef]

62. Permutt, M.A.; Chirgwin, J.; Rotwein, P.; Giddings, S. Insulin gene structure and function: A review of studies using recombinant DNA methodology. Diabetes Care 1984, 7, 386-394. [CrossRef]

63. Barratt, B.J.; Payne, F.; Lowe, C.E.; Hermann, R.; Healy, B.C.; Harold, D.; Concannon, P.; Gharani, N.; McCarthy, M.I.; Olavesen, M.G.; et al. Remapping the insulin gene/IDDM2 locus in type 1 diabetes. Diabetes 2004, 53, 1884-1889. [CrossRef]

64. Stead, J.D.H.; Hurles, M.E.; Jeffreys, A.J. Global haplotype diversity in the human insulin gene region. Genome Res. 2003, 13, 2101-2111. [CrossRef]

65. Laine, A.-P.; Holmberg, H.; Nilsson, A.; Ortqvist, E.; Kiviniemi, M.; Vaarala, O.; Akerblom, H.K.; Simell, O.; Knip, M.; Ludvigsson, J.; et al. Two insulin gene single nucleotide polymorphisms associated with type 1 diabetes risk in the Finnish and Swedish populations. Dis. Markers 2007, 23, 139-145. [CrossRef] 
66. Achenbach, P.; Lampasona, V.; Landherr, U.; Koczwara, K.; Krause, S.; Grallert, H.; Winkler, C.; Pflüger, M.; Illig, T.; Bonifacio, E.; et al. Autoantibodies to zinc transporter 8 and SLC30A8 genotype stratify type 1 diabetes risk. Diabetologia 2009, 52, 1881-1888. [CrossRef]

67. Lempainen, J.; Hermann, R.; Veijola, R.; Simell, O.; Knip, M.; Ilonen, J. Effect of the PTPN22 and INS risk genotypes on the progression to clinical type 1 diabetes after the initiation of $\beta$-cell autoimmunity. Diabetes 2012, 61, 963-966. [CrossRef]

68. Kirchhoff, K.; Machicao, F.; Haupt, A.; Schäfer, S.A.; Tschritter, O.; Staiger, H.; Stefan, N.; Häring, H.U.; Fritsche, A. Polymorphisms in the TCF7L2, CDKAL1 and SLC30A8 genes are associated with impaired proinsulin conversion. Diabetologia 2008, 51, 597-601. [CrossRef]

69. Redondo, M.J.; Geyer, S.; Steck, A.K.; Sharp, S.; Wentworth, J.M.; Weedon, M.N.; Antinozzi, P.; Sosenko, J.; Atkinson, M.; Pugliese, A.; et al. A Type 1 Diabetes Genetic Risk Score Predicts Progression of Islet Autoimmunity and Development of Type 1 Diabetes in Individuals at Risk. Diabetes Care 2018, 41, 1887-1894. [CrossRef] [PubMed]

70. Beyerlein, A.; Bonifacio, E.; Vehik, K.; Hippich, M.; Winkler, C.; Frohnert, B.I.; Steck, A.K.; Hagopian, W.A.; Krischer, J.P.; Lernmark, Å; et al. Progression from islet autoimmunity to clinical type 1 diabetes is influenced by genetic factors: Results from the prospective TEDDY study. J. Med. Genet. 2019, 56, 602-605. [CrossRef] [PubMed]

71. Steck, A.K.; Dong, F.; Wong, R.; Fouts, A.; Liu, E.; Romanos, J.; Wijmenga, C.; Norris, J.M.; Rewers, M.J. Improving prediction of type 1 diabetes by testing non-HLA genetic variants in addition to HLA markers. Pediatric Diabetes 2014, 15, 355-362. [CrossRef] [PubMed]

72. Ziegler, A.G.; Rewers, M.; Simell, O.; Simell, T.; Lempainen, J.; Steck, A.; Winkler, C.; Ilonen, J.; Veijola, R.; Knip, M.; et al. Seroconversion to multiple islet autoantibodies and risk of progression to diabetes in children. JAMA J. Am. Med. Assoc. 2013, 309, 2473-2479. [CrossRef]

73. Chmiel, R.; Giannopoulou, E.Z.; Winkler, C.; Achenbach, P.; Ziegler, A.G.; Bonifacio, E. Progression from single to multiple islet autoantibodies often occurs soon after seroconversion: Implications for early screening. Diabetologia 2015, 58, 411-413. [CrossRef] [PubMed]

74. Steck, A.K.; Johnson, K.; Barriga, K.J.; Miao, D.; Yu, L.; Hutton, J.C.; Eisenbarth, G.S.; Rewers, M.J. Age of islet autoantibody appearance and mean levels of insulin, but not GAD or IA-2 autoantibodies, predict age of diagnosis of type 1 diabetes: Diabetes autoimmunity study in the young. Diabetes Care 2011, 34, 1397-1399. [CrossRef] [PubMed]

75. Hummel, M.; Bonifacio, E.; Schmid, S.; Walter, M.; Knopff, A.; Ziegler, A.-G. Brief communication: Early appearance of islet autoantibodies predicts childhood type 1 diabetes in offspring of diabetic parents. Ann. Intern. Med. 2004, 140, 882-886. [CrossRef]

76. Ziegler, A.G.; Standl, E.; Albert, E.; Mehnert, H. HLA-associated insulin autoantibody formation in newly diagnosed type I diabetic patients. Diabetes 1991, 40, 1146-1149. [CrossRef]

77. Knip, M.; Kukko, M.; Kulmala, P.; Veijola, R.; Simell, O.; Åkerblom, H.K.; Ilonen, J. Humoral beta-cell autoimmunity in relation to HLA-defined disease susceptibility in preclinical and clinical type 1 diabetes. Am. J. Med. Genet. Semin. Med. Genet. 2002, 115, 48-54. [CrossRef]

78. Sabbah, E.; Savola, K.; Kulmala, P.; Reijonen, H.; Veijola, R.; Vähäsalo, P.; Karjalainen, J.; Ilonen, J.; Åkerblom, H.K.; Knip, M. Disease-associated autoantibodies and HLA-DQB1 genotypes in children with newly diagnosed insulin-dependent diabetes mellitus (IDDM). Clin. Exp. Immunol. 1999, 116, 78-83. [CrossRef] [PubMed]

79. Kimpimäki, T.; Erkkola, M.; Korhonen, S.; Kupila, A.; Virtanen, S.M.; Ilonen, J.; Simell, O.; Knip, M. Short-term exclusive breastfeeding predisposes young children with increased genetic risk of Type I diabetes to progressive beta-cell autoimmunity. Diabetologia 2001, 44, 63-69. [CrossRef]

80. Long, A.E.; Wilson, I.V.; Becker, D.J.; Libman, I.M.; Arena, V.C.; Wong, F.S.; Steck, A.K.; Rewers, M.J.; Yu, L.; Achenbach, P.; et al. Characteristics of slow progression to diabetes in multiple islet autoantibody-positive individuals from five longitudinal cohorts: The SNAIL study. Diabetologia 2018, 61, 1484-1490. [CrossRef] [PubMed]

81. Achenbach, P.; Hummel, M.; Thümer, L.; Boerschmann, H.; Höfelmann, D.; Ziegler, A.G. Characteristics of rapid vs slow progression to type 1 diabetes in multiple islet autoantibody-positive children. Diabetologia 2013, 56, 1615-1622. [CrossRef]

82. Jacobsen, L.M.; Bocchino, L.; Evans-Molina, C.; DiMeglio, L.; Goland, R.; Wilson, D.M.; Atkinson, M.A.; Aye, T.; Russell, W.E.; Wentworth, J.M.; et al. The risk of progression to type 1 diabetes is highly variable in individuals with multiple autoantibodies following screening. Diabetologia 2020, 63, 588-596. [CrossRef] [PubMed]

83. Chimienti, F.; Devergnas, S.; Pattou, F.; Schult, F.; Garcia-Cuenca, R.; Vandewalle, B.; Kerr-Conte, J.; Van Lommel, L.; Grunwald, D.; Favier, A.; et al. In vivo expression and functional characterization of the zinc transporter ZnT8 in glucose-induced insulin secretion. J. Cell Sci. 2006, 119, 4199-4206. [CrossRef] [PubMed]

84. Kimpimäki, T.; Kulmala, P.; Savola, K.; Kupila, A.; Korhonen, S.; Simell, T.; Ilonen, J.; Simell, O.; Knip, M. Natural history of beta-cell autoimmunity in young children with increased genetic susceptibility to type 1 diabetes recruited from the general population. J. Clin. Endocrinol. Metab. 2002, 87, 4572-4579. [CrossRef] [PubMed]

85. Decochez, K.; De Leeuw, I.H.; Keymeulen, B.; Mathieu, C.; Rottiers, R.; Weets, I.; Vandemeulebroucke, E.; Truyen, I.; Kaufman, L.; Schuit, F.C.; et al. IA-2 autoantibodies predict impending Type I diabetes in siblings of patients. Diabetologia 2002, 45, 1658-1666. [CrossRef]

86. Gullstrand, C.; Wahlberg, J.; Ilonen, J.; Vaarala, D.; Ludvigsson, J. Progression to type 1 diabetes and autoantibody positivity in relation to HLA-risk genotypes in children participating in the ABIS study. Pediatric Diabetes 2008, 9, 182-190. [CrossRef] [PubMed] 
87. Steck, A.K.; Vehik, K.; Bonifacio, E.; Lernmark, A.; Ziegler, A.G.; Hagopian, W.A.; She, J.; Simell, O.; Akolkar, B.; Krischer, J.; et al. Predictors of progression from the appearance of islet autoantibodies to early childhood diabetes: The Environmental Determinants of Diabetes in the Young (TEDDY). Diabetes Care 2015, 38, 808-813. [CrossRef]

88. Siljander, H.T.; Hermann, R.; Hekkala, A.; Lahde, J.; Tanner, L.; Keskinen, P.; Ilonen, J.; Simell, O.; Veijola, R.; Knip, M. Insulin secretion and sensitivity in the prediction of type 1 diabetes in children with advanced b-cell autoimmunity. Eur. J. Endocrinol. 2013, 169, 479-485. [CrossRef]

89. Xu, P.; Krischer, J.P. Prognostic Classification Factors Associated With Development of Multiple Autoantibodies, Dysglycemia, and Type 1 Diabetes-A Recursive Partitioning Analysis. Diabetes Care 2016, 39, 1036-1044. [CrossRef]

90. Mrena, S.; Virtanen, S.M.; Laippala, P.; Kulmala, P.; Hannila, M.L.; Åkerblom, H.K.; Knip, M. Models for predicting type 1 diabetes in siblings of affected children. Diabetes Care 2006, 29, 662-667. [CrossRef]

91. Hull, C.M.; Peakman, M.; Tree, T.I.M. Regulatory T cell dysfunction in type 1 diabetes: What's broken and how can we fix it? Diabetologia 2017, 60, 1839-1850. [CrossRef]

92. Grant, C.R.; Liberal, R.; Mieli-Vergani, G.; Vergani, D.; Longhi, M.S. Regulatory T-cells in autoimmune diseases: Challenges, controversies and-yet-unanswered questions. Autoimmun. Rev. 2015, 14, 105-116. [CrossRef]

93. Viisanen, T.; Gazali, A.M.; Ihantola, E.-L.; Ekman, I.; Näntö-Salonen, K.; Veijola, R.; Toppari, J.; Knip, M.; Ilonen, J.; Kinnunen, T. FOXP3+ Regulatory T Cell Compartment Is Altered in Children With Newly Diagnosed Type 1 Diabetes but Not in AutoantibodyPositive at-Risk Children. Front. Immunol. 2019, 10, 19. [CrossRef] [PubMed]

94. Lindley, S.; Dayan, C.M.; Bishop, A.; Roep, B.O.; Peakman, M.; Tree, T.I.M. Defective suppressor function in CD4(+)CD25(+) T-cells from patients with type 1 diabetes. Diabetes 2005, 54, 92-99. [CrossRef]

95. Pesenacker, A.M.; Wang, A.Y.; Singh, A.; Gillies, J.; Kim, Y.; Piccirillo, C.A.; Nguyen, D.; Haining, W.N.; Tebbutt, S.J.; Panagiotopoulos, C.; et al. A Regulatory T-Cell Gene Signature Is a Specific and Sensitive Biomarker to Identify Children with New-Onset Type 1 Diabetes. Diabetes 2016, 65, 1031-1039. [CrossRef] [PubMed]

96. Hundhausen, C.; Roth, A.; Whalen, E.; Chen, J.; Schneider, A.; Long, S.A.; Wei, S.; Rawlings, R.; Kinsman, M.; Evanko, S.P.; et al. Enhanced T cell responses to IL-6 in type 1 diabetes are associated with early clinical disease and increased IL-6 receptor expression. Sci. Transl. Med. 2016, 8, 356ra119. [CrossRef] [PubMed]

97. Hägglöf, B.; Blom, L.; Dahlquist, G.; Lönnberg, G.; Sahlin, B. The Swedish childhood diabetes study: Indications of severe psychological stress as a risk factor for Type 1 (insulin-dependent) diabetes mellitus in childhood. Diabetologia 1991, 34, 579-583. [CrossRef] [PubMed]

98. Zung, A.; Blumenfeld, O.; Shehadeh, N.; Dally Gottfried, O.; Rakover, Y.T.; Hershkovitz, E.; Gillis, D.; Zangen, D.; Pinhas-Hamiel, O.; Hanukoglu, A.; et al. Increase in the incidence of type 1 diabetes in Israeli children following the Second Lebanon War. Pediatric Diabetes 2012, 13, 326-333. [CrossRef]

99. Nygren, M.; Carstensen, J.; Koch, F.; Ludvigsson, J.; Frostell, A. Experience of a serious life event increases the risk for childhood type 1 diabetes: The ABIS population-based prospective cohort study. Diabetologia 2015, 58, 1188-1197. [CrossRef]

100. Harjutsalo, V.; Reunanen, A.; Tuomilehto, J. Differential transmission of type 1 diabetes from diabetic fathers and mothers to their offspring. Diabetes 2006, 55, 1517-1524. [CrossRef]

101. Weires, M.B.; Tausch, B.; Haug, P.J.; Edwards, C.Q.; Wetter, T.; Cannon-Albright, L.A. Familiality of diabetes mellitus. Exp. Clin. Endocrinol. Diabetes 2007, 115, 634-640. [CrossRef]

102. Turtinen, M.; Härkönen, T.; Parkkola, A.; Ilonen, J.; Knip, M. Characteristics of familial type 1 diabetes: Effects of the relationship to the affected family member on phenotype and genotype at diagnosis. Diabetologia 2019, 62, 2025-2039. [CrossRef] [PubMed]

103. Biasucci, G.; Benenati, B.; Morelli, L.; Bessi, E.; Boehm, G. Cesarean delivery may affect the early biodiversity of intestinal bacteria. J. Nutr. 2008, 138, 1796S-1800S. [CrossRef] [PubMed]

104. Frederiksen, B.; Kroehl, M.; Lamb, M.M.; Seifert, J.; Barriga, K.; Eisenbarth, G.S.; Rewers, M.; Norris, J.M. Infant exposures and development of type 1 diabetes mellitus: The Diabetes Autoimmunity Study in the Young (DAISY). JAMA Pediatrics 2013, 167, 808-815. [CrossRef] [PubMed]

105. Cardwell, C.R.; Stene, L.C.; Ludvigsson, J.; Rosenbauer, J.; Cinek, O.; Svensson, J.; Perez-Bravo, F.; Memon, A.; Gimeno, S.G.; Wadsworth, E.J.K.; et al. Breast-feeding and childhood-onset type 1 diabetes: A pooled analysis of individual participant data from 43 observational studies. Diabetes Care 2012, 35, 2215-2225. [CrossRef] [PubMed]

106. Lund-Blix, N.A.; Sander, S.D.; Størdal, K.; Nybo Andersen, A.M.; Rønningen, K.S.; Joner, G.; Skrivarhaug, T.; Njølstad, P.R.; Husby, S.; Stene, L.C. Infant feeding and risk of type 1 diabetes in two large scandinavian birth cohorts. Diabetes Care 2017, 40, 920-927. [CrossRef]

107. Uusitalo, U.; Lee, H.S.; Aronsson, C.A.; Vehik, K.; Yang, J.; Hummel, S.; Silvis, K.; Lernmark, Å.; Rewers, M.; Hagopian, W.; et al. Early infant diet and islet autoimmunity in the TEDDY study. Diabetes Care 2018, 41, 522-530. [CrossRef] [PubMed]

108. Ziegler, A.G.; Schmid, S.; Huber, D.; Hummel, M.; Bonifacio, E. Early Infant Feeding and Risk of Developing Type 1 DiabetesAssociated Autoantibodies. J. Am. Med. Assoc. 2003, 290, 1721-1728. [CrossRef]

109. Norris, J.M.; Barriga, K.; Klingensmith, G.; Hoffman, M.; Eisenbarth, G.S.; Erlich, H.A.; Rewers, M. Timing of Initial Cereal Exposure in Infancy and Risk of Islet Autoimmunity. J. Am. Med. Assoc. 2003, 290, 1713-1720. [CrossRef]

110. Lund-Blix, N.A.; Dong, F.; Mårild, K.; Seifert, J.; Barón, A.E.; Waugh, K.C.; Joner, G.; Størdal, K.; Tapia, G.; Stene, L.C.; et al. Gluten intake and risk of islet autoimmunity and progression to type 1 diabetes in children at increased risk of the disease: The Diabetes autoimmunity study in the young (DAISY). Diabetes Care 2019, 42, 789-796. [CrossRef] 
111. Knip, M. Environmental triggers and determinants of beta-cell autoimmunity and type 1 diabetes. Rev. Endocr. Metab. Disord. 2003, 4, 213-223. [CrossRef]

112. Knip, M.; Siljander, H. The role of the intestinal microbiota in type 1 diabetes mellitus. Nat. Rev. Endocrinol. 2016, 12, 154-167. [CrossRef] [PubMed]

113. Knip, M.; Honkanen, J. Modulation of Type 1 Diabetes Risk by the Intestinal Microbiome. Curr. Diabetes Rep. 2017, 17, 1-8. [CrossRef] [PubMed]

114. Giongo, A.; Gano, K.A.; Crabb, D.B.; Mukherjee, N.; Novelo, L.L.; Casella, G.; Drew, J.C.; Ilonen, J.; Knip, M.; Hyöty, H.; et al. Toward defining the autoimmune microbiome for type 1 diabetes. ISME J. 2011, 5, 82-91. [CrossRef] [PubMed]

115. Kostic, A.D.; Gevers, D.; Siljander, H.; Vatanen, T.; Hyötyläinen, T.; Hämäläinen, A.-M.; Peet, A.; Tillmann, V.; Pöhö, P.; Mattila, I.; et al. The dynamics of the human infant gut microbiome in development and in progression toward type 1 diabetes. Cell Host Microbe 2015, 17, 260-273. [CrossRef]

116. De Goffau, M.C.; Luopajärvi, K.; Knip, M.; Ilonen, J.; Ruohtula, T.; Härkönen, T.; Orivuori, L.; Hakala, S.; Welling, G.W.; Harmsen, H.J.; et al. Fecal microbiota composition differs between children with $\beta$-cell autoimmunity and those without. Diabetes 2013, 62, 1238-1244. [CrossRef]

117. Davis-Richardson, A.G.; Ardissone, A.N.; Dias, R.; Simell, V.; Leonard, M.T.; Kemppainen, K.M.; Drew, J.C.; Schatz, D.; Atkinson, M.A.; Kolaczkowski, B.; et al. Bacteroides dorei dominates gut microbiome prior to autoimmunity in Finnish children at high risk for type 1 diabetes. Front. Microbiol. 2014, 5, 678. [CrossRef] [PubMed]

118. De Goffau, M.C.; Fuentes, S.; van den Bogert, B.; Honkanen, H.; de Vos, W.M.; Welling, G.W.; Hyöty, H.; Harmsen, H.J.M. Aberrant gut microbiota composition at the onset of type 1 diabetes in young children. Diabetologia 2014, 57, 1569-1577. [CrossRef] [PubMed]

119. Endesfelder, D.; Engel, M.; Davis-Richardson, A.G.; Ardissone, A.N.; Achenbach, P.; Hummel, S.; Winkler, C.; Atkinson, M.; Schatz, D.; Triplett, E.; et al. Towards a functional hypothesis relating anti-islet cell autoimmunity to the dietary impact on microbial communities and butyrate production. Microbiome 2016, 4, 1-12. [CrossRef]

120. Norris, J.M.; Lee, H.-S.; Frederiksen, B.; Erlund, I.; Uusitalo, U.; Yang, J.; Lernmark, Å.; Simell, O.; Toppari, J.; Rewers, M.; et al. Plasma 25-Hydroxyvitamin D Concentration and Risk of Islet Autoimmunity. Diabetes 2018, 67, 146-154. [CrossRef]

121. Tapia, G.; Mårild, K.; Dahl, S.R.; Lund-Blix, N.A.; Viken, M.K.; Lie, B.A.; Njølstad, P.R.; Joner, G.; Skrivarhaug, T.; Cohen, A.S.; et al. Maternal and Newborn Vitamin D-Binding Protein, Vitamin D Levels, Vitamin D Receptor Genotype, and Childhood Type 1 Diabetes. Diabetes Care 2019, 42, 553-559. [CrossRef] [PubMed]

122. Ghazarian, L.; Diana, J.; Simoni, Y.; Beaudoin, L.; Lehuen, A. Prevention or acceleration of type 1 diabetes by viruses. Cell. Mol. Life Sci. 2013, 70, 239-255. [CrossRef] [PubMed]

123. Du, T.; Zhou, Z.-G.; You, S.; Lin, J.; Yang, L.; Zhou, W.-D.; Huang, G.; Chao, C. Regulation by 1, 25-dihydroxy-vitamin D3 on altered TLRs expression and response to ligands of monocyte from autoimmune diabetes. Clin. Chim. Acta 2009, 402, 133-138. [CrossRef]

124. Kaufman, D.L.; Erlander, M.G.; Clare-Salzler, M.; Atkinson, M.A.; Maclaren, N.K.; Tobin, A.J. Autoimmunity to two forms of glutamate decarboxylase in insulin-dependent diabetes mellitus. J. Clin. Investig. 1992, 89, 283-292. [CrossRef] [PubMed]

125. Yoon, J.W.; Onodera, T.; Notkins, A.L. Virus-induced diabetes mellitus. XV. Beta cell damage and insulin-dependent hyperglycemia in mice infected with coxsackie virus B4. J. Exp. Med. 1978, 148, 1068-1080. [CrossRef]

126. Krogvold, L.; Edwin, B.; Buanes, T.; Frisk, G.; Skog, O.; Anagandula, M.; Korsgren, O.; Undlien, D.; Eike, M.C.; Richardson, S.J.; et al. Detection of a low-grade enteroviral infection in the islets of langerhans of living patients newly diagnosed with type 1 diabetes. Diabetes 2015, 64, 1682-1687. [CrossRef] [PubMed]

127. Ylipaasto, P.; Klingel, K.; Lindberg, A.M.; Otonkoski, T.; Kandolf, R.; Hovi, T.; Roivainen, M. Enterovirus infection in human pancreatic islet cells, islet tropism in vivo and receptor involvement in cultured islet beta cells. Diabetologia 2004, 47, 225-239. [CrossRef]

128. Hyöty, H.; Leon, F.; Knip, M. Developing a vaccine for type 1 diabetes by targeting coxsackievirus B. Expert Rev. Vaccines 2018, 17, 1071-1083. [CrossRef]

129. Perrett, K.P.; Jachno, K.; Nolan, T.M.; Harrison, L.C. Association of Rotavirus Vaccination With the Incidence of Type 1 Diabetes in Children. JAMA Pediatrics 2019, 173, 280-282. [CrossRef]

130. Rogers, M.A.M.; Basu, T.; Kim, C. Lower Incidence Rate of Type 1 Diabetes after Receipt of the Rotavirus Vaccine in the United States, 2001-2017. Sci. Rep. 2019, 9, 7727. [CrossRef]

131. Dahlquist, G.; Blom, L.; Lönnberg, G. The Swedish childhood diabetes study-A multivariate analysis of risk determinants for diabetes in different age groups. Diabetologia 1991, 34, 757-762. [CrossRef]

132. Elding Larsson, H.; Lynch, K.F.; Lönnrot, M.; Haller, M.J.; Lernmark, A.; Hagopian, W.A.; She, J.X.; Simell, O.; Toppari, J.; Ziegler, A.G.; et al. Pandemrix ${ }^{\circledR v}$ accination is not associated with increased risk of islet autoimmunity or type 1 diabetes in the TEDDY study children. Diabetologia 2018, 61, 193-202. [CrossRef]

133. Yang, L.; Han, Y.; Nilsson-Payant, B.E.; Gupta, V.; Wang, P.; Duan, X.; Tang, X.; Zhu, J.; Zhao, Z.; Jaffré, F.; et al. A Human Pluripotent Stem Cell-based Platform to Study SARS-CoV-2 Tropism and Model Virus Infection in Human Cells and Organoids. Cell Stem Cell 2020, 27, 125-136. [CrossRef] [PubMed] 
134. Luopajärvi, K.; Savilahti, E.; Virtanen, S.M.; Ilonen, J.; Knip, M.; Akerblom, H.K.; Vaarala, O. Enhanced levels of cow's milk antibodies in infancy in children who develop type 1 diabetes later in childhood. Pediatric Diabetes 2008, 9, 434-441. [CrossRef] [PubMed]

135. Virtanen, S.M.; Nevalainen, J.; Kronberg-Kippilä, C.; Ahonen, S.; Tapanainen, H.; Uusitalo, L.; Takkinen, H.-M.; Niinistö, S.; Ovaskainen, M.-L.; Kenward, M.G.; et al. Food consumption and advanced $\beta$ cell autoimmunity in young children with HLA-conferred susceptibility to type 1 diabetes: A nested case-control design. Am. J. Clin. Nutr. 2012, 95, 471-478. [CrossRef] [PubMed]

136. Koivusaari, K.; Syrjälä, E.; Niinistö, S.; Takkinen, H.-M.; Ahonen, S.; Åkerlund, M.; Korhonen, T.E.; Toppari, J.; Ilonen, J.; Peltonen, J.; et al. Consumption of differently processed milk products in infancy and early childhood and the risk of islet autoimmunity. Br. J. Nutr. 2020, 124, 173-180. [CrossRef] [PubMed]

137. Lamb, M.M.; Miller, M.; Seifert, J.A.; Frederiksen, B.; Kroehl, M.; Rewers, M.; Norris, J.M. The effect of childhood cow's milk intake and HLA-DR genotype on risk of islet autoimmunity and type 1 diabetes: The Diabetes Autoimmunity Study in the Young. Pediatric Diabetes 2015, 16, 31-38. [CrossRef]

138. Lamb, M.M.; Frederiksen, B.; Seifert, J.A.; Kroehl, M.; Rewers, M.; Norris, J.M. Sugar intake is associated with progression from islet autoimmunity to type 1 diabetes: The Diabetes Autoimmunity Study in the Young. Diabetologia 2015, 58, 2027-2034. [CrossRef]

139. Harder, T.; Roepke, K.; Diller, N.; Stechling, Y.; Dudenhausen, J.W.; Plagemann, A. Birth weight, early weight gain, and subsequent risk of type 1 diabetes: Systematic review and meta-analysis. Am. J. Epidemiol. 2009, 169, 1428-1436. [CrossRef]

140. Baum, J.D.; Ounsted, M.; Smith, M.A. Weight Gain in Infancy and Subsequent Development of Diabetes Mellitus in Childhood. Lancet 1975, 306, 866. [CrossRef]

141. Hyppönen, E.; Kenward, M.G.; Virtanen, S.M.; Piitulainen, A.; Virta-Autio, P.; Tuomilehto, J.; Knip, M.; Åkerblom, H.K. Infant feeding, early weight gain, and risk of type I diabetes. Diabetes Care 1999, 22, 1961-1965. [CrossRef] [PubMed]

142. Couper, J.J.; Beresford, S.; Hirte, C.; Baghurst, P.A.; Pollard, A.; Tait, B.D.; Harrison, L.C.; Colman, P.G. Weight gain in early life predicts risk of islet autoimmunity in children with a first-degree relative with type 1 diabetes. Diabetes Care 2009, 32, 94-99. [CrossRef]

143. Hyppönen, E.; Virtanen, S.M.; Kenward, M.G.; Knip, M.; Åkerblom, H.K. Obesity, increased linear growth, and risk of type 1 diabetes in children. Diabetes Care 2000, 23, 1755-1760. [CrossRef]

144. Yang, J.; Lernmark, A.; Uusitalo, U.M.; Lynch, K.F.; Veijola, R.; Winkler, C.; Larsson, H.E.; Rewers, M.; She, J.X.; Ziegler, A.G.; et al. Prevalence of obesity was related to HLA-DQ in 2-4-year-old children at genetic risk for type 1 diabetes. Int. J. Obes. 2014, 38, 1491-1496. [CrossRef]

145. Larsson, H.E.; Vehik, K.; Haller, M.J.; Liu, X.; Akolkar, B.; Hagopian, W.; Krischer, J.; Lernmark, Å.; She, J.X.; Simell, O.; et al. Growth and risk for islet autoimmunity and progression to type 1 diabetes in early childhood: The environmental determinants of diabetes in the young study. Diabetes 2016, 65, 1988-1995. [CrossRef] [PubMed]

146. Lamb, M.M.; Yin, X.; Zerbe, G.O.; Klingensmith, G.J.; Dabelea, D.; Fingerlin, T.E.; Rewers, M.; Norris, J.M. Height growth velocity, islet autoimmunity and type 1 diabetes development: The Diabetes Autoimmunity Study in the Young. Diabetologia 2009, 52, 2064-2071. [CrossRef] [PubMed]

147. Nucci, A.M.; Virtanen, S.M.; Cuthbertson, D.; Ludvigsson, J.; Einberg, U.; Huot, C.; Castano, L.; Aschemeier, B.; Becker, D.J.; Knip, M.; et al. Growth and development of islet autoimmunity and type 1 diabetes in children genetically at risk. Diabetologia 2021, 64, 826-835. [CrossRef]

148. Redondo, M.J.; Steck, A.K.; Pugliese, A. Genetics of type 1 diabetes. Pediatric Diabetes 2018, 19, 346-353. [CrossRef]

149. Bakay, M.; Pandey, R.; Grant, S.F.A.; Hakonarson, H. The Genetic Contribution to Type 1 Diabetes. Curr. Diab. Rep. $2019,19,1-14$. [CrossRef]

150. Barrett, J.C.; Clayton, D.G.; Concannon, P.; Akolkar, B.; Cooper, J.D.; Erlich, H.A.; Julier, C.; Morahan, G.; Nerup, J.; Nierras, C.; et al. Genome-wide association study and meta-analysis find that over 40 loci affect risk of type 1 diabetes. Nat. Genet. 2009, 41, 703-707. [CrossRef]

151. Noble, J.A.; Erlich, H.A. Genetics of type 1 diabetes. Cold Spring Harb. Perspect. Med. 2012, 2, a007732. [CrossRef] [PubMed]

152. Swain, S.L.; McKinstry, K.K.; Strutt, T.M. Expanding roles for CD4 ${ }^{+}$T cells in immunity to viruses. Nat. Rev. Immunol. 2012, 12, 136-148. [CrossRef]

153. Noble, J.A. Immunogenetics of type 1 diabetes: A comprehensive review. J. Autoimmun. 2015, 64, 101-112. [CrossRef]

154. Hu, X.; Deutsch, A.J.; Lenz, T.L.; Onengut-Gumuscu, S.; Han, B.; Chen, W.-M.; Howson, J.M.M.; Todd, J.A.; de Bakker, P.I.W.; Rich, S.S.; et al. Additive and interaction effects at three amino acid positions in HLA-DQ and HLA-DR molecules drive type 1 diabetes risk. Nat. Genet. 2015, 47, 898-905. [CrossRef]

155. Gillespie, K.M.; Bain, S.C.; Barnett, P.A.H.; Bingley, P.P.J.; Christie, M.R.; Gill, G.V.; Gale, P.E.A.M. The rising incidence of childhood type 1 diabetes and reduced contribution of high-risk HLA haplotypes. Lancet 2004, 364, 1699-1700. [CrossRef]

156. Nejentsev, S.; Howson, J.M.M.; Walker, N.M.; Szeszko, J.; Field, S.F.; Stevens, H.E.; Reynolds, P.; Hardy, M.; King, E.; Masters, J.; et al. Localization of type 1 diabetes susceptibility to the MHC class I genes HLA-B and HLA-A. Nature 2007, 450, 887-892. [CrossRef] [PubMed]

157. Solow, H.; Hidalgo, R.; Singal, D.P. Juvenile-onset diabetes HLA-A, -B, -C, and -DR alloantigens. Diabetes 1979, 28, 1-4. [CrossRef] 
158. Rodey, G.E.; White, N.; Frazer, T.E.; Duquesnoy, R.J.; Santiago, J.V. HLA-DR specificities among black Americans with juvenileonset diabetes. N. Engl. J. Med. 1979, 301, 810-812. [CrossRef]

159. Mikk, M.L.; Heikkinen, T.; El-Amir, M.I.; Kiviniemi, M.; Laine, A.P.; Härkönen, T.; Veijola, R.; Toppari, J.; Knip, M.; Ilonen, J.;

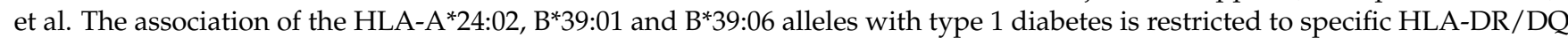
haplotypes in Finns. Hla 2017, 89, 215-224. [CrossRef]

160. Nyaga, D.M.; Vickers, M.H.; Jefferies, C.; Perry, J.K.; O'Sullivan, J.M. The genetic architecture of type 1 diabetes mellitus. Mol. Cell. Endocrinol. 2018, 477, 70-80. [CrossRef]

161. Bakay, M.; Pandey, R.; Hakonarson, H. Genes involved in type 1 diabetes: An update. Genes 2013, 4, 499-521. [CrossRef] [PubMed]

162. Fløyel, T.; Kaur, S.; Pociot, F. Genes affecting $\beta$-cell function in type 1 diabetes. Curr. Diabetes Rep. 2015, 15, 1-11. [CrossRef]

163. Smyth, D.J.; Plagnol, V.; Walker, N.M.; Cooper, J.D.; Downes, K.; Yang, J.H.M.; Howson, J.M.M.; Stevens, H.; McManus, R.; Wijmenga, C.; et al. Shared and distinct genetic variants in type 1 diabetes and celiac disease. N. Engl. J. Med. 2008, 359, 2767-2777. [CrossRef] [PubMed]

164. Evangelou, M.; Smyth, D.J.; Fortune, M.D.; Burren, O.S.; Walker, N.M.; Guo, H.; Onengut-Gumuscu, S.; Chen, W.-M.; Concannon, P.; Rich, S.S.; et al. A method for gene-based pathway analysis using genomewide association study summary statistics reveals nine new type 1 diabetes associations. Genet. Epidemiol. 2014, 38, 661-670. [CrossRef]

165. Bradfield, J.P.; Qu, H.-Q.; Wang, K.; Zhang, H.; Sleiman, P.M.; Kim, C.E.; Mentch, F.D.; Qiu, H.; Glessner, J.T.; Thomas, K.A.; et al. A genome-wide meta-analysis of six type 1 diabetes cohorts identifies multiple associated loci. PLoS Genet. 2011, 7, e1002293. [CrossRef] [PubMed]

166. Hakonarson, H.; Qu, H.-Q.; Bradfield, J.P.; Marchand, L.; Kim, C.E.; Glessner, J.T.; Grabs, R.; Casalunovo, T.; Taback, S.P.; Frackelton, E.C.; et al. A novel susceptibility locus for type 1 diabetes on Chr12q13 identified by a genome-wide association study. Diabetes 2008, 57, 1143-1146. [CrossRef]

167. Cooper, J.D.; Smyth, D.J.; Smiles, A.M.; Plagnol, V.; Walker, N.M.; Allen, J.E.; Downes, K.; Barrett, J.C.; Healy, B.C.; Mychaleckyj J.C.; et al. Meta-analysis of genome-wide association study data identifies additional type 1 diabetes risk loci. Nat. Genet. 2008, 40, 1399-1401. [CrossRef]

168. Vafiadis, P.; Bennett, S.T.; Todd, J.A.; Nadeau, J.; Grabs, R.; Goodyer, C.G.; Wickramasinghe, S.; Colle, E.; Polychronakos, C. Insulin expression in human thymus is modulated by INS VNTR alleles at the IDDM2 locus. Nat. Genet. 1997, 15, 289-292. [CrossRef]

169. Pugliese, A.; Zeller, M.; Fernandez, A.J.; Zalcberg, L.J.; Bartlett, R.J.; Ricordi, C.; Pietropaolo, M.; Eisenbarth, G.S.; Bennett, S.T.; Patel, D.D. The insulin gene is transcribed in the human thymus and transcription levels correlated with allelic variation at the INS VNTR-IDDM2 susceptibility locus for type 1 diabetes. Nat. Genet. 1997, 15, 293-297. [CrossRef]

170. Pociot, F.; Akolkar, B.; Concannon, P.; Erlich, H.A.; Julier, C.; Morahan, G.; Nierras, C.R.; Todd, J.A.; Rich, S.S.; Nerup, J. Genetics of type 1 diabetes: What's next? Diabetes 2010, 59, 1561-1571. [CrossRef]

171. Bottini, N.; Peterson, E.J. Tyrosine phosphatase PTPN22: Multifunctional regulator of immune signaling, development, and disease. Annu. Rev. Immunol. 2014, 32, 83-119. [CrossRef] [PubMed]

172. Valta, M.; Gazali, A.M.; Viisanen, T.; Ihantola, E.-L.; Ekman, I.; Toppari, J.; Knip, M.; Veijola, R.; Ilonen, J.; Lempainen, J.; et al. Type 1 diabetes linked PTPN22 gene polymorphism is associated with the frequency of circulating regulatory T cells. Eur. J. Immunol. 2020, 50, 581-588. [CrossRef] [PubMed]

173. Maccuish, A.C.; Irvine, W.J.; Barnes, E.W.; Duncan, L.J.P. Antibodies To Pancreatic Islet Cells in Insulin-Dependent Diabetics With Coexistent Autoimmune Disease. Lancet 1974, 304, 1529-1531. [CrossRef]

174. Bottazzo, G.F.; Florin-Christensen, A.; Doniach, D. Islet-cell antibodies in diabetes mellitus with autoimmune polyendocrine deficiencies. Lancet 1974, 2, 1279-1283. [CrossRef]

175. Kupila, A.; Keskinen, P.; Simell, T.; Erkkilä, S.; Arvilommi, P.; Korhonen, S.; Kimpimäki, T.; Sjöroos, M.; Ronkainen, M.; Ilonen, J.; et al. Genetic risk determines the emergence of diabetes-associated autoantibodies in young children. Diabetes 2002, 51, 646-651. [CrossRef]

176. Kimpimäki, T.; Kupila, A.; Hämäläinen, A.-M.; Kukko, M.; Kulmala, P.; Savola, K.; Simell, T.; Keskinen, P.; Ilonen, J.; Simell, O.; et al. The First Signs of $\beta$-Cell Autoimmunity Appear in Infancy in Genetically Susceptible Children from the General Population: The Finnish Type 1 Diabetes Prediction and Prevention Study. J. Clin. Endocrinol. Metab. 2001, 86, 4782-4788. [CrossRef]

177. Ziegler, A.G.; Hummel, M.; Schenker, M.; Bonifacio, E. Autoantibody appearance and risk for development of childhood diabetes in offspring of parents with type 1 diabetes: The 2-year analysis of the German BABYDIAB Study. Diabetes 1999, 48, 460-468. [CrossRef]

178. Kukko, M.; Kimpimäki, T.; Kupila, A.; Korhonen, S.; Kulmala, P.; Savola, K.; Simell, T.; Keskinen, P.; Ilonen, J.; Simell, O.; et al. Signs of beta-cell autoimmunity and HLA-defined diabetes susceptibility in the Finnish population: The sib cohort from the Type 1 diabetes prediction and prevention study. Diabetologia 2003, 46, 65-70. [CrossRef]

179. Lempainen, J.; Härkönen, T.; Laine, A.; Knip, M.; Ilonen, J.; Groop, P.H.; Lappi, A.; Otonkoski, T.; Saha, M.T.; Simell, O.; et al. Associations of polymorphisms in non-HLA loci with autoantibodies at the diagnosis of type 1 diabetes: INS and IKZF4 associate with insulin autoantibodies. Pediatric Diabetes 2013, 14, 490-496. [CrossRef]

180. Hermann, R.; Laine, A.P.; Veijola, R.; Vahlberg, T.; Simell, S.; Lähde, J.; Simell, O.; Knip, M.; Ilonen, J. The effect of HLA class II, insulin and CTLA4 gene regions on the development of humoral beta cell autoimmunity. Diabetologia 2005, 48, 1766-1775. [CrossRef] 
181. Hermann, R.; Lipponen, K.; Kiviniemi, M.; Kakko, T.; Veijola, R.; Simell, O.; Knip, M.; Ilonen, J. Lymphoid tyrosine phosphatase (LYP/PTPN22) Arg620Trp variant regulates insulin autoimmunity and progression to type 1 diabetes. Diabetologia 2006, 49, 1198-1208. [CrossRef]

182. Graham, J.; Hagopian, W.A.; Kockum, I.; Li, L.S.; Sanjeevi, C.B.; Lowe, R.M.; Schaefer, J.B.; Zarghami, M.; Day, H.L.; LandinOlsson, M.; et al. Genetic effects on age-dependent onset and islet cell autoantibody markers in type 1 diabetes. Diabetes 2002, 51, 1346-1355. [CrossRef]

183. Goodnow, C.C.; Sprent, J.; Fazekas de St Groth, B.; Vinuesa, C.G. Cellular and genetic mechanisms of self tolerance and autoimmunity. Nature 2005, 435, 590-597. [CrossRef] [PubMed]

184. Cashman, K.S.; Jenks, S.A.; Woodruff, M.C.; Tomar, D.; Tipton, C.M.; Scharer, C.D.; Eun-Hyung Lee, F.; Boss, J.M.; Sanz, I. Understanding and measuring human B-cell tolerance and its breakdown in autoimmune disease. Immunol. Rev. 2019, $292,76-89$. [CrossRef]

185. Volfson-Sedletsky, V.; Jones, A.; Hernandez-Escalante, J.; Dooms, H. Emerging Therapeutic Strategies to Restore Regulatory T Cell Control of Islet Autoimmunity in Type 1 Diabetes. Front. Immunol. 2021, 12, 1-7. [CrossRef] [PubMed]

186. Burrack, A.L.; Martinov, T.; Fife, B.T. T Cell-Mediated Beta Cell Destruction: Autoimmunity and Alloimmunity in the Context of Type 1 Diabetes. Front. Endocrinol. 2017, 8, 343. [CrossRef] [PubMed]

187. Herold, K.C.; Bundy, B.N.; Long, S.A.; Bluestone, J.A.; DiMeglio, L.A.; Dufort, M.J.; Gitelman, S.E.; Gottlieb, P.A.; Krischer, J.P.; Linsley, P.S.; et al. An Anti-CD3 Antibody, Teplizumab, in Relatives at Risk for Type 1 Diabetes. N. Engl. J. Med. 2019, 381, 603-613. [CrossRef]

188. Viisanen, T.; Ihantola, E.-L.; Näntö-Salonen, K.; Hyöty, H.; Nurminen, N.; Selvenius, J.; Juutilainen, A.; Moilanen, L.; Pihlajamäki, J.; Veijola, R.; et al. Circulating CXCR5+PD-1+ICOS+ Follicular T Helper Cells Are Increased Close to the Diagnosis of Type 1 Diabetes in Children With Multiple Autoantibodies. Diabetes 2017, 66, 437-447. [CrossRef] [PubMed]

189. Ekman, I.; Ihantola, E.-L.; Viisanen, T.; Rao, D.A.; Näntö-Salonen, K.; Knip, M.; Veijola, R.; Toppari, J.; Ilonen, J.; Kinnunen, T. Circulating CXCR5(-)PD-1(hi) peripheral T helper cells are associated with progression to type 1 diabetes. Diabetologia 2019, 62, 1681-1688. [CrossRef]

190. Ferreira, R.C.; Simons, H.Z.; Thompson, W.S.; Cutler, A.J.; Dopico, X.C.; Smyth, D.J.; Mashar, M.; Schuilenburg, H.; Walker, N.M.; Dunger, D.B.; et al. IL-21 production by CD4+ effector T cells and frequency of circulating follicular helper T cells are increased in type 1 diabetes patients. Diabetologia 2015, 58, 781-790. [CrossRef]

191. Schwedhelm, K.; Thorpe, J.; Murray, S.A.; Gavin, M.; Speake, C.; Greenbaum, C.; Cerosaletti, K.; Buckner, J.; Long, S.A. Attenuated IL-2R signaling in CD4 memory T cells of T1D subjects is intrinsic and dependent on activation state. Clin. Immunol. 2017, 181, 67-74. [CrossRef]

192. Insel, R.; Dutta, S.; Hedrick, J. Type 1 Diabetes: Disease Stratification. Biomed. Hub 2017, 2, 111-126. [CrossRef] [PubMed]

193. Barzaghi, F.; Passerini, L.; Bacchetta, R. Immune dysregulation, polyendocrinopathy, enteropathy, $x$-linked syndrome: A paradigm of immunodeficiency with autoimmunity. Front. Immunol. 2012, 3, 211. [CrossRef]

194. Rook, G.A.W. Hygiene hypothesis and autoimmune diseases. Clin. Rev. Allergy Immunol. 2012, 42, 5-15. [CrossRef]

195. Wilkin, T.J. The accelerator hypothesis: Weight gain as the missing link between Type I and Type II diabetes. Diabetologia 2001, 44, 914-922. [CrossRef] [PubMed]

196. Dahlquist, G. Can we slow the rising incidence of childhood-onset autoimmune diabetes? The overload hypothesis. Diabetologia 2006, 49, 20-24. [CrossRef]

197. Hermann, R.; Knip, M.; Veijola, R.; Simell, O.; Laine, A.P.; Åkerblom, H.K.; Groop, P.H.; Forsblom, C.; Pettersson-Fernholm, K.; Ilonen, J. Temporal changes in the frequencies of HLA genotypes in patients with Type 1 diabetes-Indication of an increased environmental pressure? Diabetologia 2003, 46, 420-425. [CrossRef] [PubMed]

198. Ilonen, J.; Lempainen, J.; Veijola, R. The heterogeneous pathogenesis of type 1 diabetes mellitus. Nat. Rev. Endocrinol. 2019, 15, 635-650. [CrossRef] [PubMed]

199. Dominguez-Bello, M.G.; Costello, E.K.; Contreras, M.; Magris, M.; Hidalgo, G.; Fierer, N.; Knight, R. Delivery mode shapes the acquisition and structure of the initial microbiota across multiple body habitats in newborns. Proc. Natl. Acad. Sci. USA 2010, 107, 11971-11975. [CrossRef]

200. Yassour, M.; Vatanen, T.; Siljander, H.; Hämäläinen, A.M.; Härkönen, T.; Ryhänen, S.J.; Franzosa, E.A.; Vlamakis, H.; Huttenhower, C.; Gevers, D.; et al. Natural history of the infant gut microbiome and impact of antibiotic treatment on bacterial strain diversity and stability. Sci. Transl. Med. 2016, 8, 343ra81. [CrossRef]

201. Stewart, C.J.; Ajami, N.J.; O’Brien, J.L.; Hutchinson, D.S.; Smith, D.P.; Wong, M.C.; Ross, M.C.; Lloyd, R.E.; Doddapaneni, H.V.; Metcalf, G.A.; et al. Temporal development of the gut microbiome in early childhood from the TEDDY study. Nature 2018, 562, 583-588. [CrossRef]

202. Siljander, H.; Honkanen, J.; Knip, M. Microbiome and type 1 diabetes. EBioMedicine 2019, 46, 512-521. [CrossRef] [PubMed]

203. Alkanani, A.K.; Hara, N.; Gottlieb, P.A.; Ir, D.; Robertson, C.E.; Wagner, B.D.; Frank, D.N.; Zipris, D. Alterations in Intestinal Microbiota Correlate With Susceptibility to Type 1 Diabetes. Diabetes 2015, 64, 3510-3520. [CrossRef]

204. Blom, L.; Nyström, L.; Dahlquist, G. The Swedish childhood diabetes study-Vaccinations and infections as risk determinants for diabetes in childhood. Diabetologia 1991, 34, 176-181. [CrossRef] [PubMed]

205. Hamming, I.; Timens, W.; Bulthuis, M.L.C.; Lely, A.T.; Navis, G.J.; van Goor, H. Tissue distribution of ACE2 protein, the functional receptor for SARS coronavirus. A first step in understanding SARS pathogenesis. J. Pathol. 2004, 203, 631-637. [CrossRef] 
206. Yang, J.-K.; Lin, S.-S.; Ji, X.-J.; Guo, L.-M. Binding of SARS coronavirus to its receptor damages islets and causes acute diabetes. Acta Diabetol. 2010, 47, 193-199. [CrossRef]

207. Li, J.; Wang, X.; Chen, J.; Zuo, X.; Zhang, H.; Deng, A. COVID-19 infection may cause ketosis and ketoacidosis. Diabetes Obes. Metab. 2020, 22, 1935-1941. [CrossRef]

208. Chee, Y.J.; Ng, S.J.H.; Yeoh, E. Diabetic ketoacidosis precipitated by Covid-19 in a patient with newly diagnosed diabetes mellitus. Diabetes Res. Clin. Pract. 2020, 164, 108166. [CrossRef] [PubMed]

209. Rubino, F.; Amiel, S.A.; Zimmet, P.; Alberti, G.; Bornstein, S.; Eckel, R.H.; Mingrone, G.; Boehm, B.; Cooper, M.E.; Chai, Z.; et al New-Onset Diabetes in Covid-19. N. Engl. J. Med. 2020, 383, 789-790. [CrossRef]

210. Zhu, L.; She, Z.-G.; Cheng, X.; Qin, J.-J.; Zhang, X.-J.; Cai, J.; Lei, F.; Wang, H.; Xie, J.; Wang, W.; et al. Association of Blood Glucose Control and Outcomes in Patients with COVID-19 and Pre-existing Type 2 Diabetes. Cell Metab. 2020, 31, 1068-1077. [CrossRef] [PubMed]

211. Docherty, A.B.; Harrison, E.M.; Green, C.A.; Hardwick, H.E.; Pius, R.; Norman, L.; Holden, K.A.; Read, J.M.; Dondelinger, F.; Carson, G.; et al. Features of 20133 UK patients in hospital with covid-19 using the ISARIC WHO Clinical Characterisation Protocol: Prospective observational cohort study. BMJ 2020, 369, m1985. [CrossRef]

212. Knip, M.; Åkerblom, H.K.; Al Taji, E.; Becker, D.; Bruining, J.; Castano, L.; Danne, T.; de Beaufort, C.; Dosch, H.-M.; Dupre, J.; et al. Effect of Hydrolyzed Infant Formula vs Conventional Formula on Risk of Type 1 Diabetes: The TRIGR Randomized Clinical Trial. JAMA 2018, 319, 38-48. [CrossRef] [PubMed]

213. Hakola, L.; Miettinen, M.E.; Syrjälä, E.; Åkerlund, M.; Takkinen, H.M.; Korhonen, T.E.; Ahonen, S.; Ilonen, J.; Toppari, J.; Veijola, R.; et al. Association of Cereal, Gluten, and Dietary Fiber Intake with Islet Autoimmunity and Type 1 Diabetes. JAMA Pediatrics 2019, 173, 953-960. [CrossRef] [PubMed]

214. Mäkinen, M.; Löyttyniemi, E.; Koskinen, M.; Vähä-Mäkilä, M.; Siljander, H.; Nurmio, M.; Mykkänen, J.; Virtanen, S.M.; Simell, O.; Hyöty, H.; et al. Serum 25-Hydroxyvitamin D Concentrations at Birth in Children Screened for HLA-DQB1 Conferred Risk for Type 1 Diabetes. J. Clin. Endocrinol. Metab. 2019, 104, 2277-2285. [CrossRef]

215. Mäkinen, M.; Mykkänen, J.; Koskinen, M.; Simell, V.; Veijola, R.; Hyöty, H.; Ilonen, J.; Knip, M.; Simell, O.; Toppari, J. Serum 25-Hydroxyvitamin D Concentrations in Children Progressing to Autoimmunity and Clinical Type 1 Diabetes. J. Clin. Endocrinol. Metab. 2016, 101, 723-729. [CrossRef]

216. Simpson, M.; Brady, H.; Yin, X.; Seifert, J.; Barriga, K.; Hoffman, M.; Bugawan, T.; Barón, A.E.; Sokol, R.J.; Eisenbarth, G.; et al. No association of vitamin D intake or 25-hydroxyvitamin D levels in childhood with risk of islet autoimmunity and type 1 diabetes: The Diabetes Autoimmunity Study in the Young (DAISY). Diabetologia 2011, 54, 2779-2788. [CrossRef]

217. Roemhild, A.; Otto, N.M.; Moll, G.; Abou-El-Enein, M.; Kaiser, D.; Bold, G.; Schachtner, T.; Choi, M.; Oellinger, R.; LandwehrKenzel, S.; et al. Regulatory T cells for minimising immune suppression in kidney transplantation: Phase I/IIa clinical trial. BMJ 2020, 371, m3734. [CrossRef]

218. Harden, P.N.; Game, D.S.; Sawitzki, B.; der Net, J.B.; Hester, J.; Bushell, A.; Issa, F.; Brook, M.O.; Alzhrani, A.; Schlickeiser, S.; et al. Feasibility, long-term safety, and immune monitoring of regulatory $\mathrm{T}$ cell therapy in living donor kidney transplant recipients. Am. J. Transplant. 2021, 21, 1603-1611. [CrossRef]

219. Chandran, S.; Tang, Q.; Sarwal, M.; Laszik, Z.G.; Putnam, A.L.; Lee, K.; Leung, J.; Nguyen, V.; Sigdel, T.; Tavares, E.C.; et al. Polyclonal Regulatory T Cell Therapy for Control of Inflammation in Kidney Transplants. Am. J. Transplant. 2017, 17, 2945-2954. [CrossRef] [PubMed] 